\title{
The role of a central actor in increasing platform stickiness and stakeholder profitability: Bridging the gap between value creation and value capture in the sharing economy
}

Pavel Laczko ${ }^{1}$, Dusana Hullova ${ }^{2}$, Andrew Needham ${ }^{3}$, Ann-Marie Rossiter ${ }^{4}$, Martina Battisti $^{5}$

${ }_{1}$ University of Portsmouth, Faculty of Business and Law, Richmond Building, Portland Street, Portsmouth, PO13 DE, UK, e: pavel.laczko@port.ac.uk t: +44 (0) 7863473074 (Corresponding author)

2 University of Portsmouth, Faculty of Business and Law, Richmond Building, Portland Street, Portsmouth, PO13 DE, UK, e: dusana.hullova@port.ac.uk t: +44 (0) 2392844093

3 Headbox Solutions, 25 Holywell Row, London, EC2 4XE, UK, e: andrew@headbox.co.uk

${ }_{4}$ Headbox Solutions, 25 Holywell Row, London, EC2 4XE, UK, e: ann-marie@headbox.co.uk

5 University of Portsmouth, Faculty of Business and Law, Richmond Building, Portland Street, Portsmouth, PO13 DE, UK, e: martina.battisti@port.ac.uk 


\section{Highlights}

- The viability of a sharing economy platform is determined by the central actor's ability to actively manage and, in the long term, maintain synergies between the value it creates and the value it appropriates.

- Development of a multi-stakeholder network in the sharing economy is not selfgoverned, but rather a well-designed process that is developed and managed by the central actor.

- We posit eight value-driving mechanisms through which the central actor can simultaneously increase platform stickiness (ability to draw in and keep stakeholders) and stakeholder profitability (ability to capture value from multiple stakeholders).

- We integrate value-driving mechanisms in the Platform Stickiness - Stakeholder Profitability Framework that not only offers novel theoretical insights, but can also be used by practitioners to improve their stakeholder management strategies.

- Our study extends the sharing economy literature into the B2B context by providing empirical insights into the UK's first-of-a-kind B2B platform that is disrupting the events industry. 


\section{Abstract}

To survive and prosper, firms need to be able to capture the value they create. The role of the central actor in developing a viable multi-stakeholder platform resides in its ability to continuously manage synergies between the value it enables and creates, and the value it appropriates. However, capturing value is more difficult than its creation, which often results in a rather short lifespan of many platform-based businesses. Existing literature, however, neglects the role of the central actor in orchestrating value in these platforms, and mostly focuses on mechanisms through which diverse stakeholders gain financial benefits and appropriate value for themselves. With an aim to contribute to this research field, we draw upon stakeholder theory and a longitudinal case study of HeadBox, the first online B2B sharing economy-based platform that enables businesses to offer and hire inspiring off-site spaces and associated services in the United Kingdom. We put forward a Platform Stickiness - Stakeholder Profitability Framework that establishes the missing connection between value creation and value appropriation by the central actor in multi-stakeholder platforms. The framework integrates eight 'value-driving' mechanisms that impact the central actor's ability to establish synergies between value creation and capture within a platform. 


\section{The role of a central actor in increasing platform stickiness and stakeholder profitability: Bridging the gap between value creation and value capture in the sharing economy}

\section{Introduction}

While the number of companies whose offering is embedded in core tenets of the sharing economy is growing, a large number of them do not enjoy a long lifespan (Plenter, Fielt, Hoffen, Chasin, \& Rosemann, 2017; Täuscher \& Kietzmann, 2017). To survive and prosper they need to be able to capture the value they create. However, "capturing value is often much more difficult than creating it” (Bock \& George, 2018, p. 80). When compared with 'traditional' economies (Cusumano, 2015), in the sharing economy “organizations do not produce resources; they provide the infrastructure for individuals [and companies] to access or share existing resources that they already possess” (Mair \& Reischauer, 2017, p. 4). This infrastructure is provided and continuously developed by the central actor, and it usually takes the form of a digital platform (Kenney \& Zysman, 2016) that not only facilitates transactions but, also enables value co-creation among all stakeholders within the network (Lindgreen \& Wynstra, 2005; Vargo \& Lusch, 2004). As postulated by Alves, Fernandes and Raposo (2016, p.1627) “co-creation occurs whenever the resources of one system integrate with those available in other service systems.” Therefore, the value is "cocreated in interaction between customers, sellers and other actors in complex B2B systems” (Marcos-Cuevas, Nätti, Palo, \& Baumann, 2016, p.97). However, the processes and structures of value co-creation are yet not well documented within the literature (Corsaro, Ramos, Henneberg, \& Naudé, 2012) and, several authors call for more research into value co-creation among multiple stakeholders at the network level (Reypens, Lievens, \& Blazevic, 2016). As postulated by Reypens et al. (2016, p.41), co-creation requires "coordination of stakeholders and their activities” which, within sharing economy platforms is undertaken by the central actor. In our context, the central actor is defined as a facilitator of the platform that is responsible for orchestrating a sharing economy platform that consists of multiple diverse stakeholders at both supply and demand sides 
(Constantiou, Marton, \& Tuunainen, 2017). These stakeholders play different roles within the platform, and usually their power, behavior, level of influence and/or interaction with the central actor and with other stakeholders changes over time (Harrison, Bosse, \& Phillips, 2007; Lappi, Haapasalo, \& Aaltonen, 2015; Santos Leitão \& Russi De Domenico, 2015). The importance and influence of different stakeholders often depend on lifecycle phase at which the platform is at the given time (Jawahar \& McLaughlin, 2001), which, leads to continually changing stakeholder dimensions (Reypens et al., 2016; Täuscher \& Kietzmann, 2017). As a result, this dynamic nature of platforms creates significant orchestration challenges for the central actor (Nambisan \& Sawhney, 2011), because it not only needs to respond to the changing roles of multiple stakeholders but, also to anticipate them (Powell \& Swart, 2010). In line with arguments put forward by Moore (1996), we consider platforms to be both, deliberate and co-evolutionary. It is the central actor that deliberately develops the platform (platform owner) however, this platform then continuously co-evolves as a result of actions, relationships, and interaction between central actor and its stakeholders, and among stakeholders themselves. Arguably, it is somewhat rare that stakeholders' roles remain static during the platform's lifecycle and therefore, in this paper we also aim to establish a dynamic stakeholder dimension that helps us to understand their changing roles and influence over the platform. In doing so, we build on the abovementioned works of Reypens et al. (2016) and Täuscher and Kietzmann (2017).

The existing definitions of platforms are often limited to product and technology aspects but, neglect the interconnected actions of different stakeholders within the network. For the purpose of this study we adopt the recent definition by Perks, Kowalkowski, Witell, and Gustafsson (2017, p. 107), who established the term 'value platforms' to describe the "dynamic configurations of (tangible and intangible) resources that act as a foundation upon which network members co-create value through a set of specific practices.” Over the years, stakeholder theory started to divert from its basic philosophical underpinnings, which are grounded in the 'interconnectedness' of stakeholders (Freeman, Harrison, \& Wicks, 2007). In essence, extant literature marginalises the relationships and interactions between the central actor and its stakeholders, and examines the role and impact of stakeholders rather from the 'entitlement' perspective: what duties a central actor has towards different stakeholders (i.e., to whom it is accountable) (Donaldson \& Preston, 
1995; Kochan \& Rubinstein, 2000). The contemporary contributions to this theory mostly ignore the role of stakeholders in creating value for the central actor and each other (Freeman, Harrison, Wicks, Parmar, \& De Colle, 2010; Harrison \& Wicks, 2013; Lankoski, Smith, \& Van Wassenhove, 2016). It is precisely the role of the central actor to ensure the sustainability of the sharing economy platform by continuously co-developing value-adding offerings with and for its diverse stakeholders while increasing value capture opportunities for itself (Dass \& Kumar, 2014; Gawer \& Cusumano, 2014; Gobble, 2014; Möller \& Svahn, 2009). The central actor can achieve this by establishing and managing a symbiotic stakeholder network that "facilitate[s] exchange and value creation” (AarikkaStenroos \& Ritala, 2017, p. 25) for all of its stakeholders. However, there is a lack of research that explores how the central actor can successfully manage these diverse stakeholders to jointly create and capture value in multi-sided platforms (Nambisan \& Sawhney, 2011; Reypens et al., 2016).

This study therefore, contributes to stakeholder theory as well as the emerging debate on the conceptualisation of the sharing economy by responding to several future research calls by Reypens et al. (2016, p. 47), Gawer and Cusumano (2014, p. 422), Harrison and Wicks (2013, p. 98), and Aarikka-Stenroos, Jaakkola, Harrison, and Mäkitalo-Keinonen (2017, p. 88) to: a) focus on investigating practices that facilitate value creation used by a central actor that is in charge of managing a multi-stakeholder innovation network; and b) improve our 'understanding [of] why central actors succeed over time [and] why stakeholders are drawn to (and remain with) some central actors.' This leads us to the following research question:

How does the central actor increase the viability of a multi-stakeholder platform in the sharing economy?

More specifically, we are interested in identifying the value-driving mechanisms that allow the central actor to create joint value, while at the same time increasing its own value capture opportunities within the platform. Drawing on a longitudinal case study of HeadBox, the first B2B online sharing platform that enables business customers to offer and hire inspiring off-site spaces (i.e., venues, conference rooms, meeting spaces) and 
associated services in the United Kingdom (UK), we propose a Platform Stickiness Stakeholder Profitability Framework. As Bock and George (2018, p. 80) postulate, “just creating something with value does not mean that the [central actor] will actually capture it.” Therefore, our framework identifies eight value-driving mechanisms through which the central actor can not only create but, also capture value across the platform. In doing so, this study establishes the missing connection between value creation and value appropriation by a central actor in multi-stakeholder platforms (Reypens et al., 2016; Harrison \& Wicks, 2013).

We structure the rest of the article as follows. First, the theoretical background section introduces the concept of the sharing economy in the B2B context, provides reasoning for the choice of our theoretical lens, and offers an overview of our existing knowledge of the central actor's role in multi-stakeholder platforms. Second, we describe the case study and, by using the principles of systematic combining, we propose the Platform Stickiness Stakeholder Profitability Framework. Next, we provide a discussion of value-driving mechanisms that lead to better stakeholder profitability and increased platform stickiness. In the remaining sections, we discuss our contributions to the theory and identify managerial implications and future research avenues.

\section{Theoretical background}

\subsection{Sharing economy}

Almost 15 years ago, Iansiti and Levien (2004, p. 1) suggested that "the strategy increasingly becomes the art of managing assets that one does not possess.” Essentially, this is the basic premise of the sharing economy in which the central actor enables its stakeholders to gain access to assets and complementary services provided by other stakeholders, who in exchange benefit in monetary but, also non-monetary ways, from providing such access (Mair \& Reischauer, 2017). Therefore, the sharing economy is often seen as a response to industry inefficiencies derived from underutilized assets and 
resources. As we have already witnessed in hospitality, transportation or pharmaceutical industry, sharing economy certainly has the potential to shake up established 'assetdominant' industries (Belk, 2014). However, despite its potential and growing popularity, the concept of the sharing economy has mainly been discussed in practitioner-focused journals (Cannon \& Summers, 2014; Sundararajan, 2016) and popular business press (Howard, 2016; Yu, 2017). The academic research on the sharing economy is still in its infancy (Richter, Kraus, Brem, Durst, \& Giselbrecht, 2017). To date, research on the sharing economy is limited to motivations to share (Bucher, Fieseler, \& Lutz, 2016; Habibi, Kim, \& Laroche, 2016; Hellwig, Morhart, Girardin, \& Hauser, 2015; Lamberton \& Rose, 2012; Möhlmann, 2015; Piscicelli, Cooper, \& Fisher, 2015), trust (Ert, Fleischer, \& Magen, 2016), competition (Cusumano, 2015) and legislation (Guttentag, 2015 Kassan \& Orsi, 2012; Koopman, Mitchell, \& Thierer, 2014). Within popular press as well as the academic journals, the Airbnb and Uber constitute some of the best-known and widely discussed examples of this phenomenon (Gerom, 2013) however, many lesser talked-about examples of successful sharing economy platforms exists within the B2B markets. An interesting example of such a platform is one developed by MedImmune, a global biologics R\&D subsidiary owned by AstraZeneca, and Merck \& Co, an American pharmaceutical company. The companies formed a 15-year manufacturing capacitysharing agreement in 2011 to utilize MedImmune’s Frederick, Maryland, facility for Merck’s bulk product manufacturing. The driver behind the partnership was MedImmune’s inability to fully utilize its plant, due to delays in product commercialization. The cost of operational expenses of staff and depreciation of the manufacturing assets was expected to reach \$100 million per year, and MedImmune did not want their staff to remain in 'standby status.' Apart from providing Merck \& Co. with access to capacity for the company's maturing biologics pipeline, both parties agreed to share microbial bulk capacity, highcapacity mAb filling, and live-virus filling (Van Arnum, 2012). Another example of a B2B sharing platform that contributes to a good cause is Fareshare, a charity that aims to relieve food poverty and reduce food waste in the UK. To achieve this, it partners with supermarkets, (i.e., Tesco, Sainsbury’s) and distributes surplus food to local charities, cooks meals for underprivileged people, while at the same time helps to reduce food waste. For instance, in 2017 Foodshare managed 16,992 tonnes of food, reached 1,500 towns, saving the charity sector $£ 28.7$ million in a single year (Fareshare, 2018). 
Participation of businesses in the sharing economy is proliferating (Botsman \& Rogers, 2011; Täuscher \& Kietzmann, 2017). To a large extent, this growth is fuelled by changing consumption patterns and advancement of technology-enabled platforms (Constantiou et al., 2017; Schwab, 2016). Businesses in the sharing economy often rely on platforms (Evans \& Schmalensee, 2010; Gawer \& Cusumano, 2014) to enable value creation and appropriation for its multi-stakeholder network (Reypens et al., 2016). These platforms not only mediate transaction between diverse stakeholders (Evans, 2003; Rochet \& Tirole, 2006) but, also enable the creation of long-term relationships between the central actor and stakeholders, and among stakeholders themselves. Essentially, in multi-sided sharing economy platforms (Hagiu, 2013; Kumar, Lahiri, \& Dogan, 2018; Muzellec, Ronteau, \& Lambkin, 2015) diverse groups of stakeholders simultaneously create and capture value; they are co-creators of the offering (Marcos-Cuevas et al., 2016; Vargo \& Lusch, 2004). This is in line with arguments put forward by Evans and Schmalensee (2010, p. 22) who postulate that stakeholders' "participation on the platform affects the quality of the product it offers" to other stakeholders (Evans \& Schmalensee, 2010). Therefore, it is these "joint actions of [stakeholders] rather than the features and attributes of products” (Perks et al., 2017, p. 106) that shape the sharing economy platform. This active role that stakeholders play in creating and shaping the sharing economy platform offering creates significant growth opportunities when compared with the ownership-based economy (Grassmuck, 2012). Constantiou et al. (2017, pp. 231-232) postulate that "what distinguishes sharing economy platforms from traditional marketplaces, supplier networks, third-party intermediaries, service integrators and such, is the way they combine organizational and market mechanisms to coordinate platform participation and, ultimately, to create value.” There are many differences between sharing economy platforms and traditional ecommerce platforms and other digital marketplaces such as Google Adwords, Amazon or eBay (see Kumar, Lahiri, \& Dogan, 2018 for the detailed comparison). However, the most fundamental difference when compared to traditional platforms is that "sharing economy platforms do not enable the selling and buying of goods but rather facilitate peer-to-peer rental and sharing, or, more broadly speaking, temporary access to goods and resources” (Constantiou et al., 2017, pp. 233-234).

Attractiveness and the value of the sharing economy platform "increases with the number of its users - the more people who use a service the more, new, people will join in” 
(Constantiou et al., 2017, p.234). As a result, this leads to increased platform stickiness. We established this term to refer to central actor's ability to continuously attract new and maintain existing stakeholders within a platform through the effective orchestration of value co-creation. Continuously increasing the stickiness of the platform is essential for achieving better stakeholder lock-in and reducing the likelihood of switching (Smedlund \& Faghankhani, 2015). As argued by Smedlund and Faghankhani (2015, p. 1385), "it is difficult to lock-in participants if the platform does not continuously offer something new and of value. As soon as the platform offering becomes static, it can be copied by a competing platform.” Kohler (2015, p.71) postulates that once the central actor can continually attract diverse stakeholders to invest their "efforts and resources, the platform's value is extended," which makes the platform even more attractive. According to Parker, Van Alstyne, and Choudary (2016), a majority of the well-designed platforms create far more value for their stakeholders than these platforms can capture. As argued by Bock and George (2018, p. 80), “capturing value is often much more difficult than creating it.” In fact, monetization "is one of the most difficult -and fascinating - issues that any platform company must address” (Parker et al., 2016, p.108). Therefore, to increase platform profitability, the central actor needs to be able to capture enough value from its stakeholder. We use this term platform profitability to refer to central actors ability to continuously develop new processes through which it increases its own value capture opportunities.

Our rationale for examining sharing economy platforms from dynamic perspective is in line with work of Vargo and Lusch (2011) who postulate that networks need to be viewed as dynamic systems where processes for value creation and capture continuously evolve (Kohler, 2015; Moser \& Gassmann, 2016). However, the relationship between the value capture and value creation within networks is yet not well understood and therefore, more work is needed in this area (Adegbesan \& Higgins, 2011; Dhanaraj \& Parkhe, 2006; Reypens et al., 2016).

\subsection{Stakeholder theory}


Stakeholders directly influence the central actor's ability to create, and appropriate value for itself and all stakeholders within the platform. In the sharing economy, the central actor does not own any assets and depends solely on its stakeholder network to provide access to these assets along with other relevant resources and services (Freeman et al., 2010). Harrison et al. (2007) argue that "specific types of stakeholder-based resources (e.g., knowledge of stakeholders' utility functions, a reputation for respecting shareholders) and capabilities (e.g., continuously forming updated value propositions for stakeholders) enable the firm [central actor] to create and appropriate value” (p. 2). Arguably, the success of a sharing economy platform depends on the attention that the central actor pays to its stakeholders' needs and interests (Freeman, 1984). However, in the multi-stakeholder platforms that are common in the sharing economy (Hagiu, 2013), the central actor is confronted with myriad, often diametrically different, needs and goals that are pursued by its diverse stakeholders. The extent to which the central actor can balance these goals over time often determines its long-term success (Letaifa, 2014). In line with the basic premise of stakeholder theory, we argue that the stakeholder network is dynamic (Fassin, 2008, 2010; Lamberg, Savage, \& Pajunen, 2003; Lamberg, Pajunen, Parvinen, \& Savage, 2008) and therefore characterised by continuous changes in power, influence, interests or behavior of stakeholders (Harrison et al., 2007). It is one of the principal roles of the central actor to keep abreast of these changes by actively managing the stakeholder network. Despite this, the vast majority of the contributions that aimed to advance stakeholder theory by establishing different stakeholder dimensions relied heavily on adopting a dichotomous view (Miles, 2017). For example, Savage et al. (1991) distinguished between 'primary’ and ‘secondary' stakeholders while Mahoney (1994) classified stakeholders based on their involvement on active and passive. However, as argued by Miles (2017, p. 441) a "major drawback of simple typologies is their inability to assess relational attributes such as proximity, connection, co-dependence, or mutual exclusivity.” We argue that the role of different stakeholders in creating, delivering and capturing value changes over time as issues faced by company and a context in which it operates are changing (Friedman \& Miles 2006; Santos Leitão \& Russi De Domenico, 2015; Winn 2001), which leads to constantly changing stakeholder dimensions (Reypens et al, 2016; Täuscher \& Kietzmann, 2017).

Stakeholder theory revolves around the concept of value and how this value is 'jointly' created by all stakeholders within a network (Freeman, 1984; Freeman et al., 2010). For 
instance, in sharing economy it is not only the value of a particular offering that is affected by stakeholders' interaction (Evans \& Schmalensee, 2010) but, they have a direct impact on the value of the entire platform (Muzellec, Ronteau, \& Lambkin, 2015). Paradoxically, as Harrison and Wicks (2013) argue, the recent advancements in stakeholder theory take 'value' and what it constitutes for granted. The authors further criticise that the "narrowing in conceptions of value tends to obscure other critical aspects of utility relevant to a discussion of value - particularly dimensions that extend beyond profitability and economic returns” (p. 100). The majority of contributions to stakeholder theory are organization-centric and look predominantly at the mechanisms through which individual companies create value for themselves by collaborating with external parties (Friedman \& Miles, 2006). However, as postulated by Agle et al. (2008, p. 166), stakeholder theory is "not a theory of the firm [but] rather it is a very simple idea about how people create value for each other." Over the years, research on stakeholder theory started to almost neglect its fundamental philosophical underpinnings, i.e., the 'interconnectedness' of stakeholders (Freeman et al., 2007). Instead, research has focused on the distribution of economic value and the right to these economic outcomes by different stakeholders. In other words, extant literature mostly neglects the interaction between stakeholders. Instead, it examines the role and impact of stakeholders from an 'entitlement' perspective, i.e., what duties the central actor has towards different stakeholders and to whom it is accountable (Donaldson \& Preston, 1995; Kochan \& Rubinstein, 2000). Ignoring the direct or indirect role that stakeholders play in creating value for the central actor and one another significantly impairs the further development of stakeholder theory (Fassin, 2012; Freeman et al., 2010; Harrison \& Wicks, 2013; Lankoski et al., 2016). Hence, it is important to conceptualize the underlying processes of value creation and its distribution (Harrison et al., 2007). However, to do so, we need to uncover the mechanisms through which stakeholders and the central actor can influence value creation and appropriation. Harrison and Wicks (2013, p. 98) suggest evaluating the definition of value in stakeholder theory and advocate to extend this construct beyond economic gains to improve our "understanding [of] why firms succeed over time [and] why stakeholders are drawn to (and remain with) some firms.” Our paper is taking this direction, and we explore the role the central actor plays in drawing in and keeping stakeholders. 


\subsection{The role of the central actor in managing stakeholders}

The role of the central actor in platform development is becoming increasingly important (Thomas, Autio, \& Gann, 2014). Growing attention that is paid to the central actor is due to the shifting focus from firm-centric innovation to network-centric innovation (Nambisan \& Sawhney, 2011), where the central actor plays a critical role in orchestrating interactions among diverse stakeholders. Despite its growing importance, the existing studies neglect or marginalize central actor's role in orchestrating these networks and instead, focus on mechanisms through which diverse stakeholders gain financial benefits and appropriate value within these networks (Nambisan \& Sawhney, 2011). The existing literature has been significantly influenced by industrial network theory (Ford, 2011; Möller \& Halinen, 2017), which argues that the central actor has limited influence over the network members and, the networks are emergent without any guidance. Contradictory to this assumption, the research on network orchestration assumes that the central actor can purposefully influence and manage the development of a value network (Müller-Seitz, 2012). To a certain extent, we agree with both views and argue that the sharing economy platform is both, deliberate and co-evolutionary (Moore, 1996). It is the central actor that deliberately develops the platform (i.e., processes and activities) however, this platform then continuously co-evolves as a result of actions, relationships, and interactions between the central actor and its stakeholders, and among stakeholders themselves. While the 'coevolution' requires the central actor to grant some control over the platform to stakeholders (Wind, Fung, \& Fung, 2009), the central actor still remains responsible for developing and orchestrating all core processes and interactions that contribute to value creation and value capture within this platform. Dhanaraj and Parkhe (2006, p. 659) define network orchestration as "the set of deliberate, purposeful actions undertaken by the hub firm [central actor] as it seeks to create value (expand the pie) and extract value (gain a larger slice of the pie) from the network." In their theoretical article, the authors propose that to create, and appropriate value from the stakeholder network, the central actor needs to ensure knowledge mobility. The knowledge mobility will function effectively in instances when the central actor is willing to provide and can access, the knowledge residing at other members of the network, learn from them, and share those learnings (Dhanaraj \& Parkhe, 2006). Another important orchestration task is to facilitate network stability by trying to avoid the rise of competitive pressures among members by, for example, creating more value for a certain group of stakeholders. To achieve this, the central actor can focus on 
building much stronger ties with stakeholders through multiplexity - increasing the number of joint projects (Dhanaraj \& Parkhe, 2006; Kenis \& Knoke, 2002).

In sharing economy, for multi-stakeholder platforms to be viable, not only for the central actor but, for all stakeholders, the central actor needs to attain the critical mass (Cusumano \& Gawer, 2002; Evans \& Schmalensee, 2010). Given the multifaceted nature of the platform, the right timing of stakeholder onboarding and integration is essential to avoid an imbalance between supply and demand. Kumar et al. (2017) argue that the central actor's long-term success depends on its ability to acquire, retain and win back profitable stakeholders. Each stakeholder has a 'customer-like power' to join or not to join the platform (Harrison \& Wicks, 2013, p. 103). Therefore, the central actor needs to draw in these stakeholders by focusing on establishing business relationships that are mutually beneficial for all network actors (Gawer \& Cusumano, 2014). Visnjic, Neely, Cennamo, and Visnjic (2016) argue that for the central actor it is imperative to establish a network that promotes participation and innovation by diverse stakeholders. As the network grows, the central actor faces an increasing number of orchestration challenges related to value creation and capture for its stakeholders (Perks et al., 2017). Growing multitude and diversity of stakeholders make this process somewhat challenging because, the central actor will need to be able to demonstrate value for all stakeholders (Paquin \& HowardGrenville, 2013). According to Freeman et al. (2010, p. 41), “many stakeholder theorists have focused on the inherent conflict between stakeholder interests and, in doing so, they have forgotten that stakeholder interests are also joint.” Therefore, instead of being fixated on differences among the stakeholders, Harrison, Freeman and Abreu (2015, p. 865) call for more research into examining and establishing 'overlapping interests of various stakeholders' that could lead to more effective stakeholder management strategies. We argue that it is precisely the role of the central actor to establish these joint interests, reinforce, and leverage them over time to continuously demonstrate value to all stakeholders within the platform.

\section{Research methods}


To uncover and gain a deeper understanding of the value-driving mechanisms through which the central actor increases stakeholder value while at the same time leveraging its own value capture opportunities, we adopted an abductive exploratory case study design (Blaikie, 2007, 2010). In essence, we explore how does the central actor increase the viability of a multi-stakeholder platform in the sharing economy. Our case study focuses on tracking the two-year development of HeadBox, the first B2B online sharing platform that enables business customers to offer and hire creative and inspiring off-site spaces (including associated services) in the UK. A longitudinal qualitative case study approach allowed us to appreciate the evolution and complexities of the iterative processes and interlinked value-driving mechanisms during different phases of the platform's development (Edmondson \& McManus, 2007; Easton, 2010; Aarikka-Stenroos \& Lehtimäki, 2014). This is fundamental to our understanding of what drives stakeholders in, why they remain with the central actor (platform stickiness) and how the central actor can capture value from multiple diverse stakeholders (stakeholder profitability). Our approach thus responds to Möller and Halinen’s (2017) call for more longitudinal studies that investigate the dynamic development of a platform rather than conducting studies that capture events at one point in time. Furthermore, there is a limited number of studies that take central actor's perspective in establishing the link between value creation and value capture in multi-stakeholder networks (Ritala, Agouridas, \& Assimakopoulos, 2013). Although, the existing literature continues to discuss the importance of establishing such a link, the contributions are predominantly theoretically derived (Lepak, Smith, \& Taylor, 2007). Makadok and Coff (2002) argue that this gap is a result of the dominance of resource-based view (RBV), whose primary objective is to explain firm profitability that is determined by value captured by the firm. Some of the well-known articles by Barney (1986) and Peteraf (1993) refer to RBV as a theory of value capture rather than of value creation. Ritala et al. (2013) is one of the few studies that identified tangible and intangible mechanisms a central actor can use in the innovation ecosystem to facilitate and ensure value creation (i.e., joint forums, meetings to communicate common vision), and value capture (i.e., contracts, agreements, plans of each actor's potential share of outcomes), not only for the central actor, but also for the entire ecosystem. In particular, the authors uncover benefits of a keystone strategy, when the central actor “ is a more flexible part of a diverse ecosystem, proactively and collaboratively developing, leveraging and sharing knowledge, capabilities, and value” (Ritala et al., p. 249). However, at the same time, the authors criticize the lack of systematic evidence on how central actors can facilitate both 
value creation and value capture in their ecosystems (Ritala et al., 2013). Our study takes on this perspective and investigates central actors' ability to orchestrate joint value creation while simultaneously increasing its value capture opportunities in the platform.

The case of HeadBox provides insights into the development and management of a sharing economy platform that disrupted the traditional venue-hiring industry in the highly neglected B2B context. This case is a unique example of a central actor that managed to develop and grow its platform by establishing and maintaining the balance between the value it enables and creates for stakeholders, and the value it appropriates. Previous studies on the sharing economy are rather descriptive and offer limited variety as they are often based on the same well-known cases in the B2C or C2C sector (Mair \& Reischauer, 2017), such as AirBnB (Guttentag, 2015; Zervas, Proserpio, \& Byers, 2017; Belk, 2014), Lyft (Sundararajan, 2016), Uber (Cannon \& Summers, 2014) or Zipcar (Bardhi \& Eckhardt, 2012). However, 'the sharing economy also offers opportunities for businesses to share with each other' (Wosskow, 2014, p. 38), but these are not yet well documented. To the best of our knowledge, this study is the first to offer these insights.

\subsection{Data collection}

Data collection spanned a two-year period, from February 2016 to March 2018. We used several sources to map out the development of HeadBox's sharing economy platform. Primary data was collected through face-to-face interviews, workshops and company visits. In total, our analysis is based on 21 semi-structured interviews and four workshops with representatives from all key business functions. We conducted repeated interviews with the founder and chief executive officer (CEO), head of marketing, head of product, head of sales, and some of HeadBox's largest corporate stakeholders. Given the diversity of respondents, the interview questions were slightly changed for different informants to gain insights specific to their field of expertise. We kept interview questions rather open and flexible to encourage informants to fully reflect on their experience without any restraints. During each interview, departures from the specific questions were allowed to pursue interesting new insights (Eisenhardt, 1989). 
In addition, we enriched our primary data by including internal documents, recent press releases and by conducting regular short follow-up phone and email interviews with a majority of the informants over the course of the study. The use of triangulation (Hinings, 1997; Sekaran \& Bougie, 2016) enabled us to not only enrich our data and provide context for the study but, also to achieve a comprehensive understanding of the sharing economy platform development and its management. In addition, a draft version of the framework was presented at a company meeting. The feedback received was used to help us improve and refine our Platform Stickiness - Stakeholder Profitability Framework.

\subsection{Data analysis}

Consistent with the principles of systematic combining, our data analysis involved matching the theory with empirical observations (Dubois \& Gadde, 2002, 2014) by continuously moving ‘back and forth’ between empirical data, existing literature and theory. The present study followed a non-linear data analysis process in which 'theoretical framework, empirical fieldwork and case analysis evolved simultaneously’ (Dubois \& Gadde, 2002, p. 554).

All interviews were recorded, transcribed and complemented with email communications, documents (i.e., press releases and internal documents), researchers' observations and meeting notes. These were then uploaded into Atlas ti7 software for qualitative analysis. The data collection and analysis took place simultaneously. The first stage in our data analysis focused on re-reading the interview transcripts several times, marking phrases, terms, and sections that expressed the informants' views in their own words, helping us to identify initial codes. The codes mainly referred to different ways through which the central actor creates value for stakeholders, and mechanisms through which the central actor manages the value appropriation across the stakeholder network. The second stage consisted of comparisons, grouping and in-depth examination of the relationships among the codes to form the first-order categories. Four stakeholder value-driving mechanisms and four corresponding mechanisms enabling the central actor to appropriate value emerged as first-order categories. During the first two stages of data analysis, the authors worked independently. The transcripts were coded independently by two coders. The intercoder reliability was manually assessed and calculated by dividing the number of units placed in the same category by the number of units coded (Prasad, 2008). It was tested in 
two phases, a pilot test of reliability when coders compared around 30 codes (inter-coder reliability coefficient 0.90 - satisfactory) that was later followed by assessment of the full sample.The extent to which the coders evaluated characteristics of a message and reached the same conclusion was around 0.85 , which was regarded as satisfactory (Campbell, Quincy, Osserman, \& Pedersen, 2013). The areas of low agreement in the coding scheme enabled the researchers to identify problems (i.e. using generic terms to describe codes, using inappropriate words or their synonyms) that were after further discussions clarified and led to higher quality results. In such instances was involved also a third researcher and majority decision rule was applied. The last step involved generating second-order themes that represent a higher level of abstraction in the coding, and at the same time, form the two main building blocks of the framework: platform stickiness and stakeholder profitability. In summary, the above steps enabled us to develop an empirically derived framework that integrates codes, first-order categories, and second-order themes. Our coding scheme is depicted in Figure 1.

To help us provide a context as well as direction for our study, we used the stakeholder theory as a sensitizing concept (Bowen 2006; Sandberg \& Tsoukas, 2011; Harrison \& Wicks, 2013). The theory served as a general sense of reference and guidance (Blumer 1954; Bowen 2006), rather than a 'fixed presentation of pregiven world' (Sandberg \& Tsoukas, 2011, p. 352). It enabled us to discover, understand and interpret central actors' ability to orchestrate joint value creation and simultaneously increase its value capture opportunities in the platform. Following principles of abductive research, we used the sensitizing concept to build interview protocol, lay the foundation for the data analysis, establish the first order categories, and to develop the second order themes (Bowen, 2006). For instance, during the process of conducting initial interviews at HeadBox, we observed that the concept of organizational affiliation proposed by Harrison and Wicks (2013) played a critical role in HeadBox's success. Stakeholders were willing to actively participate in value creation activities mainly because the central actor motivated them to do so by building a fully transparent merit-based competition between different stakeholder groups. Such dynamics incentivized stakeholders to stay and transact within the platform. 


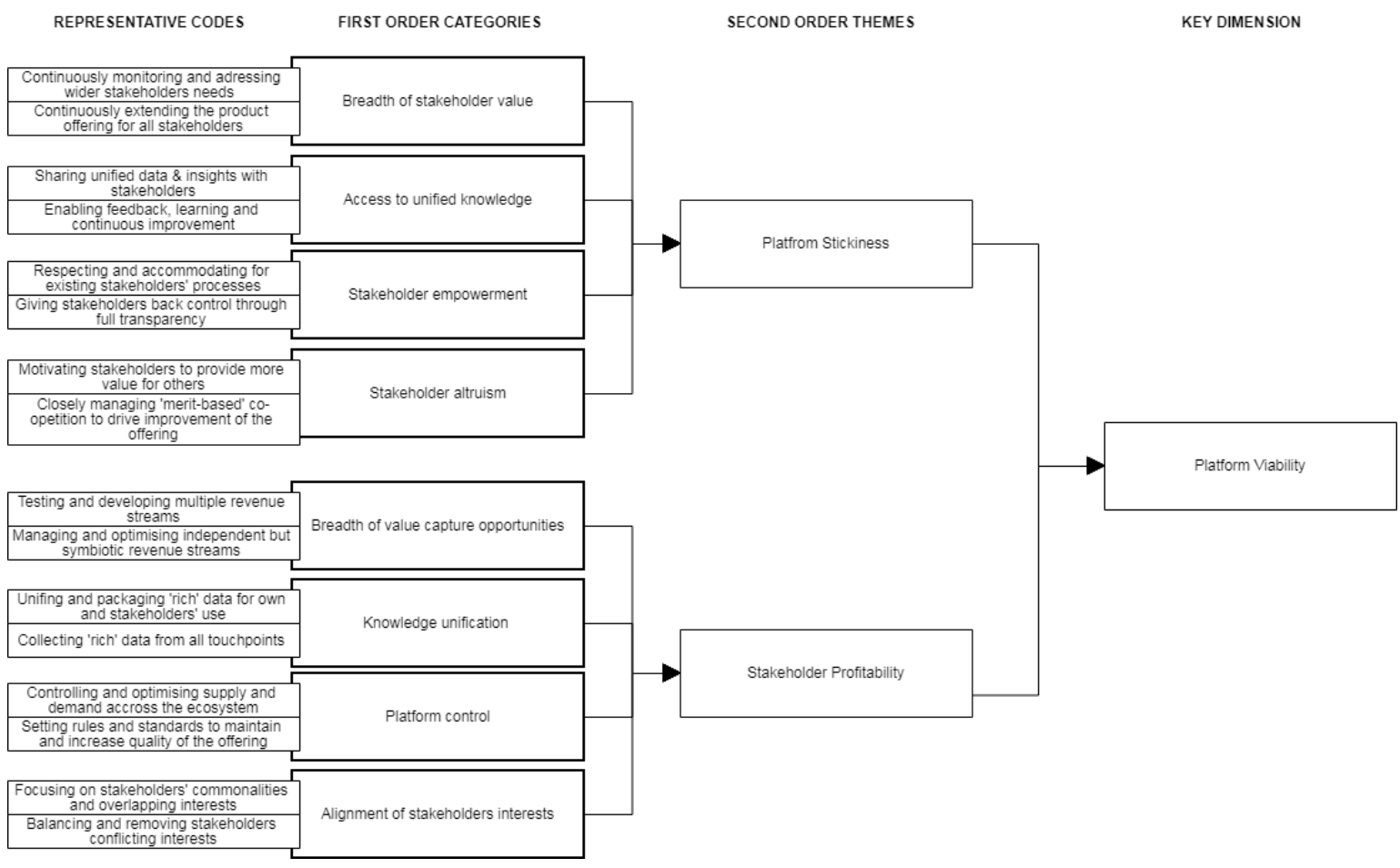

Figure 1. Coding scheme

\section{Findings}

The case study takes its starting point in the description of the central actor - HeadBox before identifying the mechanisms used to increase the viability of its multi-stakeholder platform in the B2B event industry. We put forward eight value-driving mechanisms through which HeadBox was able to: 1) draw in diverse stakeholders, 2) keep and engage these stakeholders, and 3) establish multiple monetary and non-monetary value capture strategies throughout different phases of its platform development. Building on these descriptive accounts, in the second part we present the analysis of the case and introduce our Platform Stickiness - Stakeholder Profitability Framework.

\subsection{Case study background - Introduction to HeadBox}


HeadBox is the UK's first online B2B marketplace for venues and associated services. The company launched its online platform in May 2015 with a vision to disrupt the event industry. The launch of HeadBox was in response to existing rigidities within this industry where the 'whole process of searching and paying for spaces was really painful - manual, very inefficient and time-consuming' (founder and CEO). Using novel technology, HeadBox was quick to tackle the key industry challenges, such as lack of transparency, inflexible pricing or the limited variety of spaces offered. By continuously addressing these major inefficiencies, HeadBox was able to create value for a wide range of diverse stakeholders, who as a result started to be increasingly drawn to the platform. However, the development and application of technology to tackle industry-wide problems is just one of HeadBox's competitive strengths. The company soon realized that there are many unique spaces that are not being used during certain times of the day. By opening these spaces to its customers, HeadBox was not only able to respond to business customers' growing demands for space variety (i.e., alternatives to traditional conference venues and meeting rooms) but, also to generate additional revenue for these space owners during their idle times. With new spaces being added daily, HeadBox currently offers over 10,000 of these in London, Manchester, Birmingham, and other large UK cities. Types of available spaces range from 'traditional meeting rooms through galleries, workshops, warehouses, schools, universities, churches, photographic studios, cinemas, theatres, all the way to tree houses' (founder and CEO). Since its inception, HeadBox has focused its platform offering on the critical value drivers that were becoming increasingly important for customers, but were neglected by the industry itself. The event industry 'is way behind the customer and as such it presents a whole host of opportunities' (founder and CEO). The list of the key value drivers, including the industry's current modus operandi along with the re-invention approach pioneered by HeadBox, is summarised in Table 1.

$<$ Please insert Table 1 about here $>$

Throughout the three main development phases, HeadBox has managed to move from an initial two-sided platform reliant on a single revenue stream to a multi-sided platform with multiple complementary, but independent, revenue streams in less than three years since its launch. This development was achieved by HeadBox's focus on maximizing stakeholder value and integrating new stakeholders into the platform, while actively broadening its 
own value capture opportunities. We offer an in-depth description of HeadBox's platform development in Table 2, which depicts this process across three distinct phases.

Furthermore, we also refer to some of the developments that took place in different phases and use them as examples to illustrate how the identified value driving mechanisms impacted value creation and value capture in the case of HeadBox.

$<$ Please insert Table 2 about here $>$

\subsection{Case study analysis: Towards a Platform Stickiness - Stakeholder Profitability Framework}

The first-order categories and second-order themes (see Figure 1) were used as a basis for the development of our Platform Stickiness - Stakeholder Profitability Framework, illustrated in Figure 2.

$<$ Please insert Figure 2 about here or at the end of this section $>$

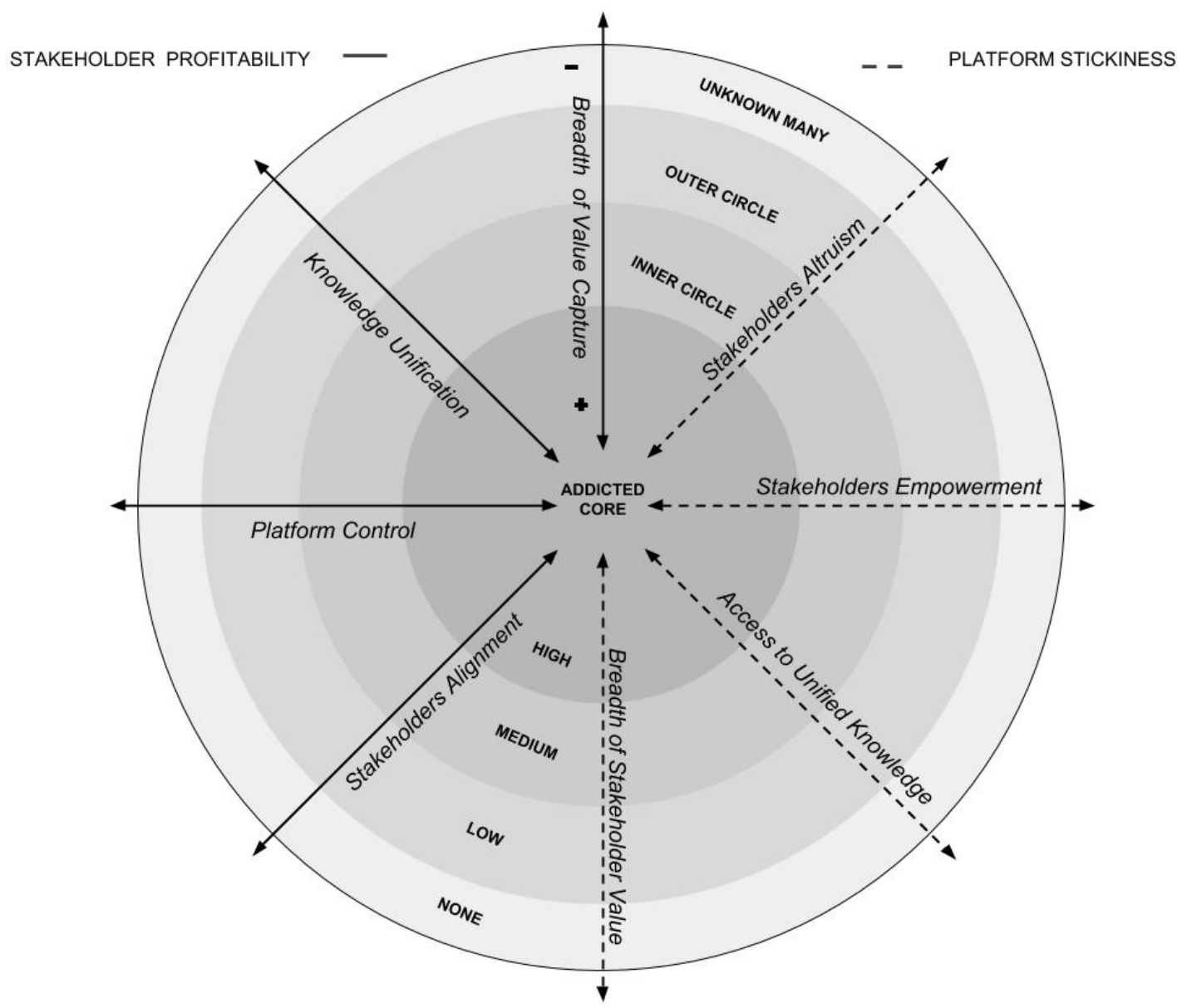


Figure 2. Platform Stickiness - Stakeholder Profitability Framework

This framework establishes the core criteria for platform viability: platform stickiness and stakeholder profitability (second-order themes). Through this framework, we demonstrate the complementary, yet, independent relationship between the two. The platform stickiness is grounded in the concept of value - a value that the central actorcan continuously create for its diverse stakeholders (i.e., by solving multiple stakeholder problems, the central actor increases their commitment and loyalty to the platform, making it 'stickier'). In essence, the stickier the platform, the more stakeholders the central actor can draw in and keep. On the other hand, stakeholder profitability is concerned with the central actor's ability to capture the value that it enables and creates for multiple stakeholders (both monetary and non-monetary value). The main argument we put forward is that the central actor's efforts to increase stickiness and profitability need to be targeted at both of these dimensions to increase the viability of a platform. For example, by solely focusing on increasing the platform's stickiness, the central actor might create more value than it can capture, resulting in a reduced ability to profit from stakeholders (unrealized potential). Equally, if the central actor captures more value than it has created, it increases its profitability, but at the same time it decreases the platform's stickiness as existing stakeholders will start switching, and fewer new stakeholders will join the platform (perceived exploitation for existing stakeholders and low attractiveness of the platform for new stakeholders). Both of these scenarios are common in the sharing economy, but failing to achieve growth in both dimensions is detrimental to the platform's viability in the long term. To achieve this, we have identified eight value-driving mechanisms (first-order categories) that shape and directly impact platform stickiness and stakeholder profitability. Because of their interrelated nature, we present these value-driving mechanisms in pairs, where each stickiness mechanism has one corresponding profitability mechanism. In doing so, we are establishing a missing link in the relationship between value capture and value creation by the central actor and other stakeholders within the sharing economy platform. Furthermore, the impact of each mechanism on its corresponding criterion (platform stickiness and stakeholder profitability) is indicated from 'none' to 'high,' forming the basis for the establishment of four stakeholder dimensions (unknown many, outer circle, inner circle, and addicted core). These dimensions correspond to the likelihood of stakeholders to not only be drawn into the platform but, also to remain with the central actor (increasing 
stickiness), which leads to increased stakeholder profitability for the central actor. The dimension 'unknown many' refers to the rather disengaged and indifferent stakeholders, who use the sharing economy platform mainly for transactional purposes - which often happens during the first phase of the platform development, as demonstrated in our case (see Table 2). Platform stickiness and stakeholder profitability are at their lowest. Both of these criteria grow as more stakeholders enter the 'outer circle' and 'inner circle' dimensions. In a sharing economy platform, both stakeholder profitability and platform stickiness reach their peak when entering the 'addicted core' dimension. In this dimension stakeholders' involvement and commitment to the central actor and other stakeholders are at their highest point. A shift from the 'unknown many' to the 'addicted core' is by no means a natural development of the platform, but it is a well-designed process that is carefully crafted and managed by the central actor (Müller-Seitz, 2012). In the case of HeadBox we mapped out this progression to start taking place in the second phase throughout the third one (see Table 2). As demonstrated in our case, HeadBox, like many other platforms before, has firstly focused on two distinct groups of stakeholders (venues and guests) for whom they provided basic value (low stickiness) and had only developed a single revenue stream (limited profitability). However, over the time, HeadBox by actively managing the identified eight value mechanisms was able to systematically develop its offering. In doing so, HeadBox has managed to not only pull its stakeholders closer to the addicted core by extending the value, but it also started to widen its own abilities to profit from the platform by introducing additional revenue streams.

'I did not have these three revenue streams when I launched HeadBox.......well I only had one when I started, so you have to take a step back, learn and focus on driving that stickiness from all sides of the marketplace [platform].' (founder \& CEO)

Arguably, only very few platforms manage to develop the addicted core (see Täuscher \& Kietzmann, 2017, who studied reasons for failures in sharing economy B2C platforms). However, doing so should be an ultimate goal of the central actor, as demonstrated in our case. In the following sections, we present eight dynamic mechanisms through which the central actor can draw its stakeholder closer to the addicted core and hence, increase the stickiness and profitability of its platform. 


\subsubsection{Stakeholder alignment (stakeholder profitability driver) and stakeholder altruism (stickiness driver)}

$<$ Please insert Figure 3 about here $>$

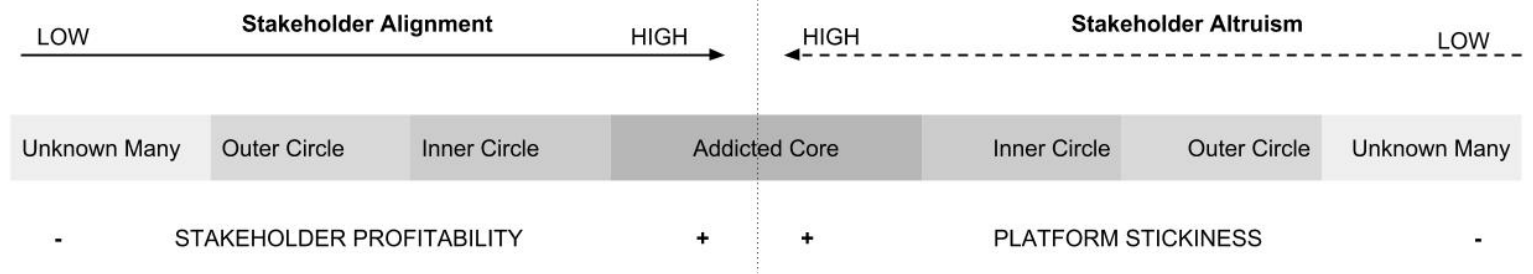

Figure 3. Stakeholder alignment vs. stakeholder altruism

The value creation among different stakeholder groups within sharing economy rests on the principles of shared values (Ouchi, 1979) and mutual collaboration that promote altruistic behavior (Hardy \& Van Vugt, 2006) among stakeholders within the sharing economy platforms. In other words, their commitment to the central actor and one another (Anderson \& Weitz, 1992) increases as a result, which leads to increased value and attractiveness of the platform (platform stickiness). However, for the central actor to establish and benefit from stakeholders' altruistic behavior, it first needs to be able to align stakeholders’ interests. In doing so, it eliminates partial conflict (Gottschlag \& Zollo, 2007) and encourages the value co-creation within the network (Harrison \& Wicks, 2013; Santos Leitão \& Russi De Domenico, 2015; Turi, Domingo-Ferrer \& Sanchez, 2018; Vargo \& Lusch, 2004), which in turn requires central actor to invest less time and resources into attending to these differences and conflicts (stakeholder profitability). When stakeholders' interests are aligned and altruistic behavior supported, the process of value creation is not dependent only on central actor's abilities and resources, but instead it becomes a shared responsibility of the entire network.

Therefore, as identified in our case, the first value-driving mechanism that influences stakeholder profitability and drives stakeholders closer to the addicted core is the central actor's ability to align stakeholder interests. This ensures that, to some extent, all stakeholders are not only able to benefit from the central actor's activities, but also from the activities of other stakeholders within the platform (Gawer \& Cusumano, 2014; Visnjic et al., 2016). Achieving this level of alignment resides in the central actor's ability to seek out and address stakeholders' joint interests rather than focusing on prioritization of one group of stakeholders over another. However, stakeholder interests are often 'in a partial 
conflict' (Freeman et al., 2010, p. 28). To sustainably increase and maintain stakeholder profitability, the central actor needs to develop its offering in a way that adds value to multiple stakeholders within the platform. In the case of HeadBox, the clear demonstration of this was when in the third phase of its platform development, the company launched the 'widget.' This widget enabled hosts to integrate HeadBox's platform into their existing IT system, which allowed them to manage all their bookings from across all channels in one place. The widget also created more transparency and enabled guests to see real-time availability of the venues. Furthermore, given that the widget could function independently, venues that were not part of HeadBox's platform were also able to use it. This not only increased the attractiveness of its platform among this group of stakeholders, but it slowly started converting these independent users into engaged customers. Therefore, by adapting its offering, HeadBox managed to address the demands of different stakeholders with the single offering (guests and hosts) and also to draw in new stakeholders (independent venues), which would not be possible without first aligning the interests of its stakeholders.

'The booking and payment widget came when quite a lot of venues started asking us if they can integrate our software with what they have on their site. At the same time guests were asking for real-time venue availability on the platform.' (head of marketing)

Furthermore, by creating value for multiple stakeholders through advancing the platform's offering, the central actor is able to capture more value by seeking revenue from all stakeholders for whom it created value. By charging an annual subscription fee for using the widget and monetising the data generated by this widget, HeadBox was able to develop additional revenue stream and thus increase the profitability of the platform.

'Whether as space chooses to join our platform, or just use the widget on a standalone website we will still have the information about the engagement of how people interact with the software. [In addition], the widget created additional revenues that we had not really thought about when we launched HeadBox.' (founder \& CEO)

However, pursuing activities that would only create value for one stakeholder group while destroying value for others needs to be avoided. For example, for HeadBox it is possible to charge an additional fee for allowing paid listings on its venue search engine result page (similar to Google Adwords), but the HeadBox is strongly against this practice. While 
these paid listings would increase value capture opportunities from stakeholders who are willing to pay for inclusion and hence, create an additional revenue stream for HeadBox, pursuing this 'in-search advertising model' is not in the interest of all stakeholders. On the guest-side of the platform, stakeholders might start losing trust in HeadBox if it favors and promotes hosts that are on the top of the listing not because of their relevance or quality, but merely because they have paid to be there. Also, this can create conflict on the venueside where venues that work hard to keep improving the quality of their offering to organically rise in ranking (HeadBox is using algorithm similar to Google that ranks venues based on combination of multiple relevancy factors and performance indicators) are likely to feel cheated and demotivated by those that simply pay to leapfrog others.

'We would never do paid listing ... putting results at the top of the search results pages of the venues that have paid to be there just doesn't really sit in line with us. What we want for everyone is to have a great experience and we want our guests to keep coming back and we want them to have access to really honest metrics on the venues.' (head of marketing)

By increasing stakeholder alignment, the central actor is also able to establish some form of reciprocal relationship among its diverse stakeholders. However, to increase platform stickiness through this reciprocity, it is imperative for the central actor to continuously reinforce stakeholder altruism, which leads to higher levels of cooperative behavior among stakeholders (Axelrod \& Hamilton, 1981; Hardy \& Van Vugt, 2006; Van Lange \& Semin-Goossens, 1998). A high level of stakeholder altruism is important both for drawing in new stakeholders and keeping existing ones (Kumar et al., 2017). To achieve this, the central actor needs to motivate stakeholders to actively participate in value co-creation activities (Visnjic et al., 2016). In our case, the central actor focused on rewarding altruistic behavior by developing algorithms that enabled establishment of a fully transparent meritbased competition where those, who create more value for other stakeholders were rewarded by having, for example, a higher organic ranking, which in the case of hosts led to increased exposure and hence more value capture opportunities.

'Hosts have the ability to improve their [organic] ranking and get themselves on the top of the search result pages, and this is what we are encouraging. But to improve their position they will have to work for it - they will have to improve their response time, improve their profile or make sure that their reviews reflect the services they offer.' (head of marketing) 



\subsubsection{Platform control (stakeholder profitability driver) vs. stakeholder empowerment (stickiness driver)}

$<$ Please insert Figure 4 about here $>$

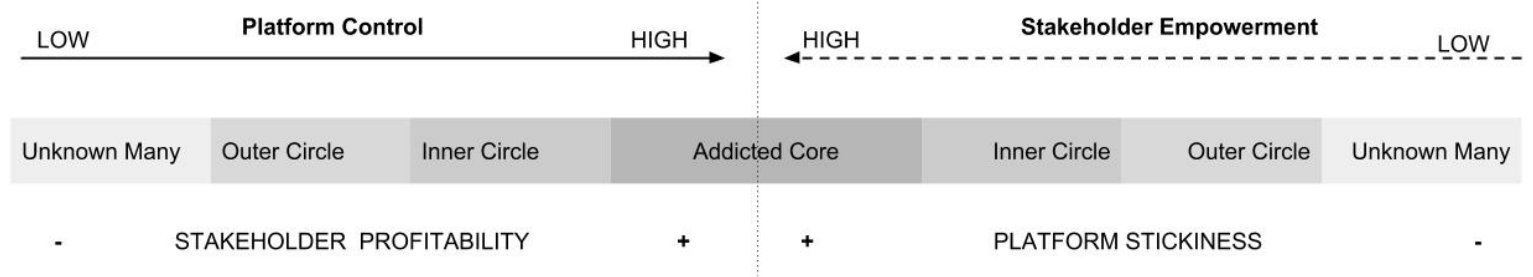

Figure 4. Platform control vs. stakeholder empowerment

Orchestrating a multi-stakeholder network requires a more fluid approach than for instance management of internal processes (firm level). To achieve this fluidity, the central actor needs to be able to empower all stakeholders, but at the same time maintain control of the platform (Wind et al., 2009). This will help the central actor to lower the barriers to entry for stakeholders and make them feel like equal partners in the platform (i.e., by integrating their existing internal processes). As further argued by Wind et al. (2009), empowering stakeholders to drive changes and managing activities that are primarily related to day-today functioning of the platform (Wind et al. 2009) will allow the central actor to direct its attention towards maintaining a strategic control of the platform (Gawer, 2014; Scholten \& Scholten, 2012). As demonstrated in our case, for the central actor to draw stakeholders closer to the addicted core, it needs to focus on accommodating their rigid and often limited, existing internal processes without attempting to standardize and force stakeholders to comply. As argued by Edelman (2015, p. 97), “platforms must offer enough compatibility to showcase potential benefits, yet not so much that users delay switching to reap those benefits.” In other words, the central actor needs to empower stakeholders to allow them to drive changes, such as letting stakeholders introduce and enforce their own cancellation policies or pricing models that are compatible with their existing systems.

'We need to work around their existing processes. If that is not the case, it is a big objection for them [stakeholders] to use our platform. Step that we took in that direction was recognising that they have internal processes that need to be 
respected and we are going to have higher chances of success if we embrace those processes. [Therefore], we started investing in features around invoicing, document workflows, we enabled corporate clients to pay by invoice as opposed to credit cards.' (head of product)

By standardizing some of these processes, the central actor can arguably gain better control over its stakeholders but, at the same time, it will create barriers to entry for many potential stakeholders. For example, HeadBox during the second phase of its platform development was quick to realise that its stakeholders' pricing models differ significantly and hence it started moving away from a single standardized pricing (i.e., rental based on $£$ per hour) and instead introduced flexible pricing models where stakeholders had full control over how they will charge their customers.

'They can now buy the space by the hour, by the day, by minimum spend, by day hire or pay per delegate. The host of those spaces wants to sell that space by applying different price models. We were the first; it has never been done in the industry before, but this is what the venues want.' (founder and CEO)

In addition to accommodating stakeholders' current pricing models, HeadBox had applied a similar approach to its cancellation policy, which again was standardized at the early stage of HeadBox's platform development (phase 1).

'At the start, all the cancellation policies were standardised. But in reality, the amount of exceptions that pushed us to deviate from those cancellation policies was quite overwhelming and we gave full control of cancellation policies to the hosts instead of holding onto it ourselves.' (head of product)

Empowering stakeholders may create an impression that the central actor will start losing control of the platform. However, as demonstrated by Headbox, the central actor can increase its platform control, while at the same time increasing stakeholder empowerment. To do so, it needs to establish a technological infrastructure through which all processes can be monitored and optimized. This infrastructure also provides stakeholders with tools and processes to function more independently. We have uncovered in our case that there are two facets to platform control. The first is operational control, where the central actor is concerned with the day-to-day management of the booking process. In the case of HeadBox, operational control has mostly been delegated to stakeholders by empowering them to take care of the process themselves through, e.g., 
managing their listings, setting prices and communicating directly with other stakeholders. The second type of control is related to the strategic management of the platform, and it is crucial for the central actor to fully control this itself. The primary focus here is on maintaining the long-term viability of the platform by balancing supply and demand, stakeholder onboarding, integration and development, and optimization of a platform-wide offering. Successful onboarding at all ends of the market (i.e., hosts, guests, corporates, service providers) is key to the success of a platform-based business (Rochet \& Tirole, 2003). Furthermore, the central actor needs to be able to avoid and manage the negative impact associated with the network effect (Boudreau \& Jeppesen, 2015; Gawer \& Cusumano, 2014; Moser \& Gassmann, 2016; Van Alstyne, Parker, \& Choudary, 2016). This is in line with the findings of Kumar et al. (2017), who stress the need for the central actors to retain only those stakeholders that create sufficient value for the platform. For instance, each new venue is assessed by HeadBox to evaluate whether it meets the predetermined set of standards needed for joining the platform in the first place. By controlling the demand and supply, the central actor can onboard only those stakeholders that are beneficial for others (i.e., have a higher predisposition for reciprocal altruism). In doing so, the central actor can fully control the quality of the offering (Evans \& Schmalensee, 2010) without falling victim to network effects. This level of control is crucial for maintaining the long-term viability of the platform.

'We have a limited amount of suppliers in each category. If you have hundreds of suppliers, only a few get regular business, which will make our offering less appealing and for them less profitable.' (founder and CEO)

Quality needs to be controlled at all ends of the platform. As Kohler (2015, p. 74) suggests, the central actor needs to be able to "create different feedback loops that encourage stakeholders to participate in the curation process through reporting, voting, or reviewing the core value unit.” It is not only the central actor that has obligations towards its various stakeholders but in sharing economy, also stakeholders have obligations towards the central actor and other stakeholders within the network (Fassin, 2012; Freeman et al., 2010; Harrison \& Wicks, 2013; Lankoski, Smith, \& Van Wassenhove, 2016). For example, in the case of HeadBox, guests have to leave detailed feedback; otherwise they are not able to use any other features or make future bookings through the platform. In essence, the curation is integrated into the core offering. 
'It is mandatory; you have to leave a review. You can't use anything on HeadBox until you have left the review. The layer [pop-up box] will follow you around and block everything until you have left a review.' (head of sales)

In our case, HeadBox started empowering its stakeholders since the first phase of its development, and it continued to do so. As a result, the company was not only able to make the platform easier to use for the existing stakeholders, but in doing so, it also managed to lower the barriers to entry and hence attract new stakeholders to the platform (increasing platform stickiness). By allowing stakeholders to take care of pricing, content, or cancelation policies, HeadBox could instead dedicate more time and resources on more strategic developments such as new services, quality control or stakeholder onboarding. These savings were directly reflected in increased platform profitability and better strategic focus.

\subsubsection{Knowledge unification (stakeholder profitability driver) and access to unified knowledge (stickiness driver)}

$<$ Please insert Figure 5 about here $>$

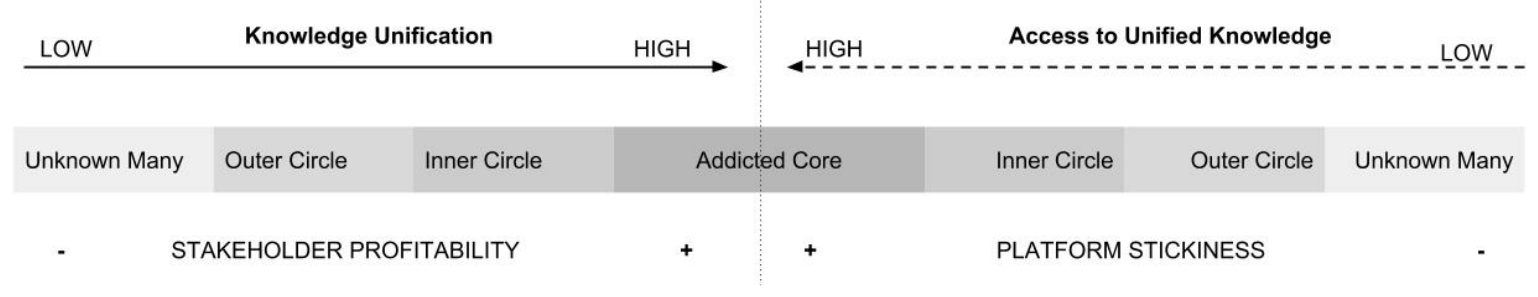

Figure 5. Knowledge unification vs. access to unified knowledge

A critical form of value capture from the platform is through collecting, analyzing and consequent unifying of the data by the central actor. This not only enables the central actor to capture value by discovering emerging stakeholder needs but, also to create value for its diverse stakeholders by providing access to collected information and thus opening an opportunity to improve the value they provide to other stakeholders within the network (Kohler, 2015). Opportunities for creating value are often uncertain, and the central actor needs to actively search for such opportunities (i.e., getting access to unique information or resources) (Rumelt, 1984). For the central actor to increase its ability to profit from its 
stakeholders, having a comprehensive understanding of their needs and interests is crucial. This can only be achieved through a continuous collection and analysis of stakeholder data from a range of sources (Dhanaraj \& Parkhe, 2006; Möller \& Svahn, 2009; Müller-Seitz, 2012). However, to benefit from this data, the central actor needs to be able to unify it. The process of knowledge unification enables the central actor to attribute data from diverse sources to a particular stakeholder. In our case, HeadBox, during the second phase of its platform development has created a sophisticated framework that allows them to unify knowledge across all data sources.

'Our data tracking framework utilizes augmented metadata that we now capture and track and this is allowing us to unify data about customer acquisition across all channels, including offline. In a very granular level, we capture a lot of key events [actions] on the system in a structured way so that we can analyse and act on it later.' (head of product)

The ability to unify knowledge often leads to early discovery of latent and emerging needs that can then be translated into additional revenue streams.

'When we looked at our database we realized that there were 10-15 people [individual accounts] from the same company using HeadBox that were often paying by using shared budgets. Based on this data, we launched the Corporate Dashboard, which broadened our reach and created an additional revenue stream.' (founder and CEO)

To increase the stickiness of the platform and the stakeholders' ability to continuously improve the offering (Evans \& Schmalensee, 2010), it is crucial that the central actor enables stakeholders to access unified knowledge. In the third phase of its platform development, HeadBox started to provide access to relevant real-time data to all of its stakeholders. In doing so, HeadBox started to drive the continuous improvement within the entire platform and put itself into the position of a data hub.

'HeadBox gets a lot of activity on its platform and so it can analyze all this data and derive the trends and see what the behavior tends to be and then use this information to augment offering.' (head of product)

For example, over the course of its platform development, this unified data led to the introduction of flexible pricing, launch of widget, customized cancellation policies and integration of 3rd party services (i.e catering, music or venue decoration services), which 
not only increased stickiness of the platform but, also its overall profitability. Furthermore, for stakeholders to also benefit from this knowledge, it needs to be not only unified and accessible but, also relevant to their evolving needs (Dhanaraj \& Parkhe, 2006). It is the role of the central actor to ensure that all stakeholders have access to the knowledge in a form that they can act upon.

'We utilize data that we are tracking on the platform, but we also package this data and use it to benefit hosts, corporates and guests. For example, hosts can use data to benchmark themselves on different factors [rating, response time, price, etc.] and see how they perform on these when compared with others and then use these insights to improve.' (head of marketing)

This commitment to continuous improvement on the hosts' side has positively impacted guests' uptake and regularity at which they used HeadBox’s platform. By giving stakeholders access to this unified knowledge, the central actor can get them to take an active part in the innovation and wider development of the offering, which in turn, increases both stakeholder profitability and platform stickiness. HeadBox was not only able to monetize its data and thus increase its value capture opportunities, but by allowing full transparency for guests, and innovation opportunities for hosts, it draws both of these stakeholder groups closer to the addicted core (i.e., they have become more involved and committed) and hence increasing the platform stickiness.

\subsubsection{Breadth of value capture (stakeholder profitability driver) and breadth of stakeholder value (stickiness driver)}

$<$ Please insert Figure 6 about here $>$

\begin{tabular}{|c|c|c|c|c|c|c|c|}
\hline LOW & \multicolumn{2}{|c|}{ Breadth of Value Capture } & $\mathrm{HIGH}$ & \multicolumn{4}{|c|}{ Breadth of Stakeholder Value } \\
\hline Unknown Many & Outer Circle & Inner Circle & & Core & Inner Circle & Outer Circle & Unknown Many \\
\hline - & TAKEHOLDER & FITABILITY & + & + & PLATFORM & KINESS & - \\
\hline
\end{tabular}

Figure 6. Breath of value capture vs. breath of stakeholder value 
Zhu and Furr (2016) postulate that while products produce only a single revenue stream, platforms can generate many. This is somewhat oversimplified because for the central actor to get closer to multiplying its revenue streams, it needs to be able to develop and support multiple types of value that its diverse stakeholder demand (Paquin \& HowardGrenville, 2013; Reypens et al., 2016). Therefore, continuously increasing stakeholder value is one of the main prerequisites not only for drawing stakeholders closer to the addicted core but, also for attracting new ones to the platform. Doing so is crucial for increasing the platform's viability and should, therefore, be embedded in its wider value proposition.

'Our value proposition drives everything. It drives our growth and it is key to our strategy. Our purpose is the most important. We change and extend what we do and how we to do it, but never the why.' (founder and CEO)

The central actor, instead of growing the platform by focusing on increasing the number of stakeholders, should be concerned with broadening stakeholder value. For instance, throughout the second and third phase of its platform development, HeadBox focused on identifying and addressing wider needs of the narrower market, rather than widening up its existing market (e.g., growing the number of venues). For example, during the second phase, HeadBox rather than solely focusing on growing its stakeholder base focused on increasing the commitment and involvement of existing stakeholders through provision of additional value (i.e., account management, bespoke services, additional payment options, private consultations), which led to significantly higher retention rate. Many of the HeadBox's existing corporate clients started using HeadBox exclusively for all of their event needs.

'After we have started to broaden our offering many of our corporate customers [stakeholders using corporate dashboard] have decided to introduced HeadBox across the whole network. We have become the one and only supplier through which they book all venues and related services.' (head of product)

For the long-term viability of the platform, it is crucial to always aim to address broader stakeholder needs instead of primarily trying to exploit the existing ones. As argued by Wind et al. (2009, p. 313) central actor sometimes needs to "sacrifice its own short-term interests to optimize the network - which benefits itself and its partners in the long run.” 
'They [stakeholders] have different, varied needs and we wanted to accommodate all those needs in one place, so we have to keep the breadth. When we talk about our offering, we always go beyond the very narrow need for a space, and we try to accommodate all other possible needs that they can have.' (head of product)

By continuously extending the breadth of stakeholder value during the first two phases of the platform development HeadBox started to see a significant increase in inbound inquiries. Initially, HeadBox had to approach and persuade some of the well known and prestigious venues to get them onto the platform but, during the third phase, these venues started to come to HeadBox.

'Some venues were quite anxious about listing themselves on HeadBox when we have just started out. They were quite precious about their brand and what has been really great, we have seen many of those venues actually re-approach us and say; now we know you are doing really well, we want to be involved.'

(head of marketing)

The high failure rate among platform-based businesses is usually caused by an unclearly defined value proposition (Clemons, 2009; Täuscher \& Kietzmann, 2017) but, also by the central actor's heavy reliance on a revenue model that is often based on a single revenue stream (i.e., commission). Equally, as the central actor continuously increases the breadth of stakeholder value, it needs to be able to benefit from the creation of this additional value (Bock \& George, 2018) and hence also broaden its own value capture opportunities. As demonstrated in our case, HeadBox, instead of exploiting its commission-based revenue model, started focusing on the development of additional revenue streams. They did this by increasing the breadth of value created for stakeholders. This not only led to increased platform stickiness but, also improved the overall profitability of the platform. For example, in addition to commissions from bookings that HeadBox was relying on during the first phase of its platform development, it managed to introduce annual subscription fees (Corporate Dashboard and payment/booking engine - widget) and paid-for services for hosts (3D tours of venues) during the subsequent phases.

'I like this idea of having three "revenue legs" to a stool. I always like to think of it in this analogy because it means the chair with two legs would make you fall over. At the beginning our revenue model was transaction-based only. Only later we 
introduced an additional subscription-based revenue model. But I didn't have these when I launched HeadBox; I only had one when I started.' (founder and CEO)

It is important to note that all of these additional revenue models while being complementary, are not interdependent, which makes the platform even more viable in the long term. Headbox has created multiple revenue streams that are interconnected, but at the same time they are entirely independent (i.e., losing one revenue stream would have no adverse impact on others).

"They [revenue streams] are all linked... the more venues we get, the more bookings we get, the more opportunities there are to sell marketing packages and drive revenue from those venues. Our revenue streams are all interconnected, but they are driven by different things. Say if one month we made x amount from commissions, that would not have a direct effect on the other revenue streams. If one month we do not do enough venue sales, it does not mean we do not get enough marketing sales or subscriptions.' (head of marketing)

Once the central actor is able to establish multiple revenue streams, the sharing economy platform is much easier to scale and expand internationally (Sundararajan, 2013). It is the central actor's ability to continuously increase the breadth of value capture opportunities by addressing broader stakeholder needs that determines the profitability of its platform.

\section{Discussion and conclusion}

The role of the central actor in developing a viable multi-stakeholder sharing economy platform resides in its ability to continuously explore, evaluate and act upon emerging opportunities to create and appropriate value. We introduced eight value-driving mechanisms through which the central actor creates value for its diverse multi-stakeholder platform and at the same time increases its own value capture opportunities.

This study responds to several calls for empirical examination to uncover not only how the central actor can attract and keep stakeholders, but also how it can succeed over time (Reypens et al., 2016; Harrison \& Wicks, 2013). Drawing on stakeholder theory and a longitudinal case of a B2B sharing economy platform, we have advanced the literature on the sharing economy and established the missing connection between value creation and 
appropriation by the central actor in multi-stakeholder platforms. Therefore, our contribution is threefold. First, we contribute to the scarce literature on network orchestration, which claims that the central actor can deliberately influence and manage the development of a value network (Dhanaraj \& Parkhe, 2006; Müller-Seitz, 2012). Findings from our case study point to eight value-driving mechanisms through which the central actor can develop an 'addicted core' and drive stakeholders closer towards it. Within the 'addicted core,' the involvement and commitment of stakeholders to the central actor and other stakeholders reaches its highest point. We refer to this process as a creation of platform stickiness. The mechanisms facilitating platform stickiness and value creation for stakeholders include stakeholder altruism; stakeholder empowerment; access to unified knowledge; and breadth of stakeholder value. Furthermore, we have empirically derived that each value-creating mechanism has a complementary, yet independent, valueappropriating mechanism (i.e., stakeholder alignment, platform control, knowledge unification, and breadth of value capture). Through these value-driving mechanisms, the central actor can monetize value created for its stakeholders and hence increase the profitability of the platform. Hence, our study contributes to a neglected stream of research that focuses on mechanisms through which the central actor can create and simultaneously appropriate value in multi-stakeholder networks (Dhanaraj \& Parkhe, 2006; Nambisan \& Sawhney, 2011; Perks et al., 2017). In essence, we build upon prior research that has highlighted the importance of linking the value creation efforts with the monetization opportunities by the central actor (Parker et al., 2016). We emphasize the complementarity between identified mechanisms enabling the value creation (platform stickiness) and value appropriation (stakeholder profitability) in the Platform Stickiness - Stakeholder Profitability Framework. Our framework illustrates value-driving mechanisms in pairs (i.e., each stickiness mechanism has a corresponding stakeholder profitability mechanism), further stressing their interrelated nature and the importance of each dimension for developing a viable platform. We believe that the central actor needs to be able to maintain synergies between these dimension in the long term to ensure that it; firstly, can capture a proportion of a value it creates, and secondly that it creates enough value for its stakeholders when compared to the value it captures for itself. Furthermore, we contribute to the existing research on stakeholder theory that has predominantly focused on responsibilities and obligations (mainly monetary) that the central actor has towards its various stakeholders (Fassin, 2012; Freeman et al., 2010; Lankoski et al., 2016). In contrast, our study provides insights into duties and obligations that stakeholders have 
towards the central actor and one another. In the sharing economy, stakeholders are not merely passive recipients of value, but they are also its co-creators. We posit that it is the role of the central actor to turn passive stakeholders (unknown many) into active and committed ones (addicted core). In doing so, the central actor can increase not only the stakeholder value but, also its own profitability. Our study presents eight mechanisms through which the central actor can initiate and manage this transition. Hence, we also respond to calls for adopting a more dynamic perspective in exploring the central actor's management of its stakeholders (Lamberg et al., 2003, 2008; Fassin, 2008, 2010). As stated by Rong, Wu, Shi, and Guo, (2015, p. 294), the power of platforms lies in their underlying mechanisms that make it 'possible to transform a passive social network into an active value creation chain.' Finally, our study extends the prior literature on the sharing economy that has been predominantly built on a limited number of well-known case studies (AirBnB and Uber) in the B2C and C2C markets (Richter, Kraus, \& Syrjä, 2015; Mair \& Reischauer, 2017). We contribute to this line of research by providing empirical insights from a unique case study of a company that introduced the first B2B sharing economy platform into the UK's event industry. Thus, we provide further evidence that the sharing economy also presents opportunities for businesses to share among themselves (Wosskow, 2014).

\subsection{Managerial implications and future research}

Along with contributing to stakeholder theory and extending the emerging debate on the sharing economy, our study also posits several implications for managers. As postulated by Freeman (1984), a firm's success depends on the attention that managers pay to its stakeholders' needs and interests. Based on our data analysis, we have developed a framework that can guide managers in identifying, addressing and profiting from these needs and interests. In essence, our framework acts as a tool that managers can use to increase the effectiveness of their stakeholder management strategies, especially in diverse multi-stakeholder networks. The framework offers several applications that practitioners can explore. First, managers can use our framework as a roadmap for the development of sharing economy platforms. Plenter et al. (2017) posit that platform-based businesses in the sharing economy have a high failure rate and this is often due to the discord between the 
value they create and the value they can capture (Clemons, 2009; Parker et al., 2016). Therefore, by adopting our framework, managers can increase the viability of their platform offering by simultaneously increasing its stickiness and profitability. This means that managers can not only achieve but, also leverage the synergies between value creation and value capture activities. Second, advisors and investors can use this framework as a diagnostic tool for identifying gaps in value capture and creation opportunities in sharing economy platform-based businesses they are advising or are considering investing in. Both managers and potential investors by using this framework can quickly evaluate and benchmark the current performance of a platform against all eight dynamic mechanisms. For instance, this will enable managers to; establish focus and priorities, aiding the development of strategies and actions needed for addressing the current situation, or setting targets and benchmarks. Furthermore, in the case of investors, use of our framework can lead to more accurate evaluation of otherwise difficult-to-evaluate types of business that SE platforms often are. Lastly, applicability and the use of our proposed framework can be extended beyond SE platform-based businesses context. We posit that managers from all businesses that serve diverse stakeholder groups can use this framework to increase stickiness and profitability of their offering through effective and more strategic stakeholder management. Opportunities for creating value are often uncertain, and managers need to actively engage in a search for such opportunities (Rumelt, 1984). Therefore, we believe that our framework will be a valuable addition to many managers' arsenal of tools used for development and profiting from stakeholder value. To conclude, we acknowledge that the present paper has several limitations that provide areas for future research. Our findings are limited to a single case, and therefore we recommend future research to adopt methods that could enhance the generalisability of our findings. Future empirical studies could also try to validate our Platform Stickiness - Stakeholder Profitability Framework and extend it to include moderating factors for the identified value-driving mechanisms. In our case, the development of the addicted core took around two years, and we believe that this timeframe is contingent upon different factors that can also be explored in future studies. While we have identified and argued the existence of a strong link between the dynamic mechanisms that drive platform stickiness and profitability, future studies can examine the importance of achieving and maintaining a balance between the two. Lastly, this study examines platforms operating in the sharing economy, but we believe that our findings can be extended beyond this context and we would like to see future studies take up this challenge. 


\section{Acknowledgements}

We would like to thank the anonymous reviewers for providing us with very insightful and inspiring comments that enabled us to significantly improve the quality of our paper. We are indebted to the amazing team at HeadBox who dedicated their time to this project and shared their valuable knowledge and experience with us. Last but not least we like to express our gratitude to Professor Johan Frishammar for not only introducing us to the abductive logic but, also for his academic mentorship.

\section{References}

Aarikka-Stenroos, L., \& Lehtimäki, T. (2014). Commercializing a radical innovation: Probing the way to the market. Industrial Marketing Management, 43(8), 1372-1384. Aarikka-Stenroos, L., \& Ritala, P. (2017). Network management in the era of ecosystems: Systematic review and management framework. Industrial Marketing Management, 67, 23-36.

Aarikka-Stenroos, L., Jaakkola, E., Harrison, D., \& Mäkitalo-Keinonen, T. (2017). How to manage innovation processes in extensive networks: A longitudinal study. Industrial Marketing Management, 67, 88-105.

Adegbesan, J. A., \& Higgins, M. J. (2011). The intra-alliance division of value created through collaboration. Strategic Management Journal, 32(2), 187-211.

Agle, B. R., Donaldson, T., Freeman, R. E., Jensen, M. C., Mitchell, R. K., \& Wood, D. J. (2008). Dialogue: Toward superior stakeholder theory. Business Ethics Quarterly, 18(2), 153-190.

Alves, H., Fernandes, C., \& Raposo, M. (2016). Value co-creation: Concept and contexts of application and study. Journal of Business Research, 69(5), 1626-1633.

Anderson, E., \& Weitz, B. (1992). The use of pledges to build and sustain commitment in distribution channels. Journal of Marketing Research, 29(1), 18-34.

Axelrod, R., \& Hamilton, W. D. (1981). The evolution of cooperation. Science, 211(4489), 1390-1396.

Bardhi, F., \& Eckhardt, G. M. (2012). Access-based consumption: The case of car sharing. Journal of Consumer Research, 39(4), 881-898.

Barney, J. B. (1986). Strategic factor markets: Expectations, luck and business strategy. Management Science, 42, 1231-1241. 
Belk, R. (2014). You are what you can access: Sharing and collaborative consumption online. Journal of Business Research, 67(8), 1595-1600.

Blaikie, N. (2007). Approaches to social enquiry: Advancing knowledge. Cambridge: Polity Press.

Blaikie, N. (2010). Designing social research: The logic of anticipation (2nd ed.). Cambridge: Polity Press.

Blumer, H. (1954). What is wrong with social theory?. American sociological review, 19(1), 3-10.

Bock, A. J., \& George, G. (2018). The business model book: Design, build and adapt business ideas that thrive. London: Pearson Education Limited.

Botsman, R., \& Rogers, R. (2011). What's mine is yours: How collaborative consumption is changing the way we live. New York: HarperCollins Business.

Boudreau, K. J., \& Jeppesen, L. B. (2015). Unpaid crowd complementors: The platform network effect mirage. Strategic Management Journal, 36(12), 1761-1777.

Bowen, G. A. (2006). Grounded theory and sensitizing concepts. International Journal of Qualitative Methods, 5(3), 12-23.

Bucher, E., Fieseler, C., \& Lutz, C. (2016). What's mine is yours (for a nominal fee): Exploring the spectrum of utilitarian to altruistic motives for Internet-mediated sharing. Computers in Human Behavior, 62, 316-326.

Campbell, J. L., Quincy, C., Osserman, J., \& Pedersen, O. K. (2013). Coding in-depth semistructured interviews: Problems of unitization and intercoder reliability and agreement. Sociological Methods \& Research, 42(3), 294-320.

Cannon, S., \& Summers, L. H. (2014). How Uber and the sharing economy can win over regulators. Harvard Business Review, 13(10), 24-28.

Clemons, E. K. (2009). Business models for monetizing internet applications and web sites: Experience, theory, and predictions. Journal of Management Information Systems, 26(2), 15-41.

Constantiou, I., Marton, A., \& Tuunainen, V. K. (2017). Four Models of Sharing Economy Platforms. MIS Quarterly Executive, 16(4), 231-251.

Corsaro, D., Ramos, C., Henneberg, S. C., \& Naudé, P. (2012). The impact of network configurations on value constellations in business markets-The case of an innovation network. Industrial Marketing Management, 41(1), 54-67.

Cusumano, M. A. (2015). How traditional firms must compete in the sharing economy. Communications of the ACM, 58(1), 32-34.

Cusumano, M. A., \& Gawer, A. (2002). The elements of platform leadership. MIT Sloan Management Review, 43(3), 51.

Dass, M., \& Kumar, S. (2014). Bringing product and consumer ecosystems to the strategic forefront. Business Horizons, 57(2), 225-234. 
Dhanaraj, C., \& Parkhe, A. (2006). Orchestrating innovation networks. Academy of Management Review, 31(3), 659-669.

Donaldson, T., \& Preston, L. E. (1995). The stakeholder theory of the corporation: Concepts, evidence, and implications. Academy of Management Review, 20(1), 65-91.

Dubois, A., \& Gadde, L. E. (2002). Systematic combining: An abductive approach to case research. Journal of Business Research, 55(7), 553-560.

Dubois, A., \& Gadde, L. E. (2014). Systematic combining: A decade later. Journal of Business Research, 67(6), 1277-1284.

Easton, G. (2010). Critical realism in case study research. Industrial Marketing Management, 39(1), 118-128.

Edelman, B. (2015). Does Google leverage market power through tying and bundling?. Journal of Competition Law \& Economics, 11(2), 365-400.

Edmondson, A. C., \& McManus, S. E. (2007). Methodological fit in management field research. Academy of Management Review, 32(4), 1246-1264.

Eisenhardt, K. M. (1989). Agency theory: An assessment and review. Academy of Management Review, 14(1), 57-74.

Ert, E., Fleischer, A., \& Magen, N. (2016). Trust and reputation in the sharing economy: The role of personal photos in Airbnb. Tourism Management, 55, 62-73.

Evans, D. S. (2003). Some empirical aspects of multi-sided platform industries. Review of Network Economics, 2, 191-209.

Evans, D. S., \& Schmalensee, R. (2010). Failure to launch: Critical mass in platform businesses. Review of Network Economics, 9(4), Article 1.

Fareshare (2018). Our Impact - More than meals. Retrieved 22 July 2018 from http://fareshare.org.uk/what-we-do/our-impact/

Fassin, Y. (2008). Imperfections and shortcomings of the stakeholder model's graphical representation. Journal of Business Ethics, 80(4), 879-888.

Fassin, Y. (2010). A dynamic perspective in Freeman's stakeholder model. Journal of Business Ethics, 96(1), 39.

Fassin, Y. (2012). Stakeholder management, reciprocity and stakeholder responsibility. Journal of Business Ethics, 109(1), 83-96.

Ford, D. (2011). IMP and service-dominant logic: Divergence, convergence and development. Industrial Marketing Management, 40(2), 231-239.

Freeman, R. E. (1984). Strategic management: A stakeholder approach. Boston: Pitman.

Freeman, R. E., Harrison, J. S., \& Wicks, A. C. (2007). Managing for stakeholders: Survival, reputation, and success. New Haven, CT: Yale University Press.

Freeman, R. E., Harrison, J. S., Wicks, A. C., Parmar, B. L., \& De Colle, S. (2010). Stakeholder theory: The state of the art. Cambridge: Cambridge University Press. 
Friedman, A. L., \& Miles, S. (2006). Stakeholders: Theory and practice. Oxford: Oxford University Press.

Gawer, A. (2014). Bridging differing perspectives on technological platforms: Toward an integrative framework. Research Policy, 43(7), 1239-1249.

Gawer, A., \& Cusumano, M. A. (2014). Industry platforms and ecosystem innovation. Journal of Product Innovation Management, 31(3), 417-433.

Gerom, T. (2013). The share economy. Forbes Magazine, 11 February, No. 1, 58-66.

Gobble, M. M. (2014). Charting the innovation ecosystem. Research-Technology Management, 57(4), 55-59.

Gottschalg, O., \& Zollo, M. (2007). Interest alignment and competitive advantage. Academy of Management Review, 32(2), 418-437.

Grassmuck, V. R. (2012). The sharing turn: Why we are generally nice and have a good chance to cooperate our way out of the mess we have gotten ourselves into. In W. Sützl, F. Stalder, R. Maier, \& T. Hug (Eds.), Cultures and ethics of sharing / Kulturen und Ethiken des Teilens. Innsbruck: Innsbruck University Press.

Guttentag, D. (2015). Airbnb: Disruptive innovation and the rise of an informal tourism accommodation sector. Current Issues in Tourism, 18(12), 1192-1217.

Habibi, M. R., Kim, A., \& Laroche, M. (2016). From sharing to exchange: An extended framework of dual modes of collaborative non ownership consumption. Journal of the Association for Consumer Research, 1(2), 277-294.

Hagiu, A. (2013). Strategic decisions for multisided platforms. MIT Sloan Review.

Retrieved 16 March 2018 from https://sloanreview.mit.edu/article/strategic-decisions-formultisided-platforms/

Hardy, C. L., \& Van Vugt, M. (2006). Nice guys finish first: The competitive altruism hypothesis. Personality and Social Psychology Bulletin, 32(10), 1402-1413.

Harrison, J. S., Bosse, D., \& Phillips, R. A. (2007). Stakeholder theory and competitive advantage. In Academy of Management Proceedings, 2007(1), 1-6.

Harrison, J. S., Freeman, R. E., \& Abreu, M. C. S. D. (2015). Stakeholder Theory As an Ethical Approach to Effective Management: applying the theory to multiple contexts. Revista Brasileira de Gestão de Negócios, 17(55), 858-869.

Harrison, J. S., \& Wicks, A. C. (2013). Stakeholder theory, value, and firm performance. Business Ethics Quarterly, 23(1), 97-124.

Hellwig, K., Morhart, F., Girardin, F., \& Hauser, M. (2015). Exploring different types of sharing: A proposed segmentation of the market for 'sharing' businesses. Psychology \& Marketing, 32(9), 891-906.

Hinings, C. R. (1997). Reflections on processual research. Scandinavian Journal of Management, 13(4), 493-503. 
Howard, B. (2016). What does the sharing economy and good housekeeping have in common? Forbes. Retrieved 16 March 2018 from

https:/www.forbes.com/sites/billeehoward/2016/07/22/what-does-the-sharing-economygood-housekeeping-have-in-common/\#732c40092f0a

Iansiti, M., \& Levien, R. (2004). The keystone advantage: What the new dynamics of business ecosystems mean for strategy, innovation, and sustainability. Boston: Harvard Business School Press.

Jawahar, I. M., \& McLaughlin, G. L. (2001). Toward a descriptive stakeholder theory: An organizational life cycle approach. Academy of Management Review, 26(3), 397-414.

Kassan, J., \& Orsi, J. (2012). The legal landscape of the sharing economy. Journal of Environmental Law \& Litigation, 27, 1-20.

Kenis, P., \& Knoke, D. (2002). How organizational field networks shape interorganizational tie-formation rates. Academy of Management Review, 27(2), 275-293.

Kenney, M., \& Zysman, J. (2016). The rise of the platform economy. Issues in Science and Technology, 32(3), 61.

Kochan, T. A., \& Rubinstein, S. A. (2000). Toward a stakeholder theory of the firm: The Saturn partnership. Organization Science, 11(4), 367-386.

Kohler, T. (2015). Crowdsourcing-based business models: how to create and capture value. California Management Review, 57(4), 63-84.

Koopman, C., Mitchell, M., \& Thierer, A. (2014). The sharing economy and consumer protection regulation: The case for policy change. Journal of Business Entrepreneurship \& Law, 8, 529-546.

Kumar, V., Lahiri, A., \& Dogan, O. B. (2017). A strategic framework for a profitable business model in the sharing economy. Industrial Marketing Management. Retrieved 16 March 2018 from https://doi.org/10.1016/j.indmarman.2017.08.021

Lamberg, J. A., Pajunen, K., Parvinen, P., \& Savage, G. T. (2008). Stakeholder management and path dependence in organizational transitions. Management Decision, 46(6), 846-863.

Lamberg, J. A., Savage, G. T., \& Pajunen, K. (2003). Strategic stakeholder perspective to ESOP negotiations: The case of United Airlines. Management Decision, 41(4), 383-393.

Lamberton, C. P., \& Rose, R. L. (2012). When is ours better than mine? A framework for understanding and altering participation in commercial sharing systems. Journal of Marketing, 76(4), 109-125.

Lankoski, L., Smith, N. C., \& Van Wassenhove, L. (2016). Stakeholder judgments of value. Business Ethics Quarterly, 26(2), 227-256.

Lappi, T., Haapasalo, H., \& Aaltonen, K. (2015). Business Ecosystem Definition in Built Environment Using a Stakeholder Assessment Process. Management (18544223), 10(2), 110-129. 
Leitão, S. D. S., \& Domenico, S. M. R. D. (2015). Looking at Organizational Change Through the construction and reconstruction of the underpinning values of the organization through interactions among stakeholders. Revista Brasileira de Gestão de Negócios, 17(55), 959-986.

Lepak, D. P., Smith, K. G., \& Taylor, M. S. (2007). Value creation and value capture: a multilevel perspective. Academy of Management Review, 32(1), 180-194.

Letaifa, B. S. (2014). The uneasy transition from supply chains to ecosystems: The valuecreation/value-capture dilemma. Management Decision, 52(2), 278-295.

Lindgreen, A., \& Wynstra, F. (2005). Value in business markets: What do we know? Where are we going?. Industrial Marketing Management, 34(7), 732-748.

Mair, J., \& Reischauer, G. (2017). Capturing the dynamics of the sharing economy: Institutional research on the plural forms and practices of sharing economy organizations. Technological Forecasting and Social Change, 125, 11-20.

Makadok, R., \& Coff, R. (2002). The theory of value and the value of theory: Breaking new ground versus reinventing the wheel. Academy of Management Review. 27(1), 10-13.

Marcos-Cuevas, J., Nätti, S., Palo, T., \& Baumann, J. (2016). Value co-creation practices and capabilities: Sustained purposeful engagement across B2B systems. Industrial Marketing Management, 56, 97-107.

Miles, S. (2017). Stakeholder theory classification: A theoretical and empirical evaluation of definitions. Journal of Business Ethics, 142(3), 437-459.

Moore, J.F. 1996. The Death of Competition: Leadership \& Strategy in the Age of Business Ecosystems. New York: Harper Business.

Möhlmann, M. (2015). Collaborative consumption: Determinants of satisfaction and the likelihood of using a sharing economy option again. Journal of Consumer Behaviour, 14(3), 193-207.

Möller, K., \& Halinen, A. (2017). Managing business and innovation networks: From strategic nets to business fields and ecosystems. Industrial Marketing Management, 67, 522.

Möller, K., \& Svahn, S. (2009). How to influence the birth of new business fields: Network perspective. Industrial Marketing Management, 38(4), 450-458.

Moser, D., \& Gassmann, O. (2016). Innovating platform business models. XXVII ISPIM Innovation Conference 2016, Porto, 2016.

Müller-Seitz, G. (2012). Leadership in interorganizational networks: A literature review and suggestions for future research. International Journal of Management Reviews, 14(4), 428-443.

Muzellec, L., Ronteau, S., \& Lambkin, M. (2015). Two-sided Internet platforms: A business model lifecycle perspective. Industrial Marketing Management, 45, 139-150. 
Nambisan, S., \& Sawhney, M. (2011). Orchestration processes in network-centric innovation: Evidence from the field. Academy of Management Perspectives, 25(3), 40-57.

Ouchi, W. G. (1979). A conceptual framework for the design of organizational control mechanisms. Readings in Accounting for Management Control. 63-82.

Parker, G. G., Van Alstyne, M. W., \& Choudary, S. P. (2016). Platform revolution: How networked markets are transforming the economy and how to make them work for you. New York: WW Norton \& Company.

Paquin, R. L., \& Howard-Grenville, J. (2013). Blind dates and arranged marriages: Longitudinal processes of network orchestration. Organization Studies, 34(11), 1623-1653.

Perks, H., Kowalkowski, C., Witell, L., \& Gustafsson, A. (2017). Network orchestration for value platform development. Industrial Marketing Management, 67, 106-121.

Peteraf, M. A. (1993). The cornerstones of competitive advantage: a resource-based view. Strategic Management Journal, 14(3), 179-191.

Piscicelli, L., Cooper, T., \& Fisher, T. (2015). The role of values in collaborative consumption: Insights from a product-service system for lending and borrowing in the UK. Journal of Cleaner Production, 97, 21-29.

Plenter, F., Fielt, E., Hoffen, M., Chasin, F., \& Rosemann, M. (2017). Repainting the business model canvas for peer-to-peer sharing and collaborative consumption. In Proceedings of the 25th European Conference on Information Systems (ECIS), 2234-2249, ISBN 978-989-20-7655-3.

Powell, J. H., \& Swart, J. (2010). Mapping the values in B2B relationships: A systemic, knowledge-based perspective. Industrial Marketing Management, 39(3), 437-449.

Prasad, B. D. (2008). Content analysis. Research Methods for Social Work, 5, 1-20.

Reypens, C., Lievens, A., \& Blazevic, V. (2016). Leveraging value in multi-stakeholder innovation networks: A process framework for value co-creation and capture. Industrial Marketing Management, 56, 40-50.

Richter, C., Kraus, S., Brem, A., Durst, S., \& Giselbrecht, C. (2017). Digital entrepreneurship: Innovative business models for the sharing economy. Creativity and Innovation Management, 26(3), 300-310.

Richter, C., Kraus, S., \& Syrjä, P. (2015). The shareconomy as a precursor for digital entrepreneurship business models. International Journal of Entrepreneurship and Small Business, 25(1), 18-35.

Ritala, P., Agouridas, V., Assimakopoulos, D., \& Gies, O. (2013). Value creation and capture mechanisms in innovation ecosystems: a comparative case study. International Journal of Technology Management, 63(3-4), 244-267.

Rochet, J. C., \& Tirole, J. (2003). Platform competition in two-sided markets. Journal of the European Economic Association, 1(4), 990-1029. 
Rochet, J. C., \& Tirole, J. (2006). Two-sided markets: A progress report. RAND Journal of Economics, 37(3), 645-667.

Rong, K., Wu, J., Shi, Y., \& Guo, L. (2015). Nurturing business ecosystems for growth in a foreign market: Incubating, identifying and integrating stakeholders. Journal of International Management, 21(4), 293-308.

Rumelt, R. P. (1984). Towards a strategic theory of the firm. In R. B. Lamb (Ed.), Competitive strategic management. Englewood Cliffs, NJ: Prentice-Hall (pp. 556-570).

Schwab, K. (2016). The fourth industrial revolution. New York: Crown Publishing Group.

Sandberg, J., \& Tsoukas, H. (2011). Grasping the logic of practice: Theorizing through practical rationality. Academy of Management Review, 36(2), 338-360.

Sekaran, U., \& Bougie, R. (2016). Research methods for business: A skill building approach. Hoboken, NJ: John Wiley \& Sons.

Smedlund, A., \& Faghankhani, H. (2015). Platform orchestration for efficiency, development, and innovation. In System Sciences (HICSS), 2015, 48th Hawaii International Conference on System Sciences IEEE,1380-1388.

Sundararajan, A. (2013). From Zipcar to the sharing economy. Harvard Business Review. Retrieved 16 March 2018 from https://hbr.org/2013/01/from-zipcar-to-the-sharing-eco Sundararajan, A. (2016). The sharing economy: The end of employment and the rise of crowd-based capitalism. Cambridge, MA: The MIT Press.

Täuscher, K. \& Kietzmann, J. (2017). Learning from failures in the sharing economy. MIS Quarterly Executive, 16(4), 253-264.

Thomas, L. D., Autio, E., \& Gann, D. M. (2014). Architectural leverage: Putting platforms in context. Academy of Management Perspectives, 28(2), 198-219.

Turi, A. N., Domingo-Ferrer, J., \& Sánchez, D. (2018). Problems in the undertakings of the collaborative economy: Co-utile solutions. In Co-utility. Domingo-Ferrer, J. \& Sánchez, D. (Eds). Cham: Springer.

Van Alstyne, M. W., Parker, G. G., \& Choudary, S. P. (2016). Pipelines, platforms, and the new rules of strategy. Harvard Business Review, 94(4), 54-62.

Van Arnum, P. (2012). Manufacturing Capacity-Sharing Model: Merck \& Co. and MedImmune LLC. Pharmtech.com, 8(4). Retrieved 22 July 2018 from http://www.pharmtech.com/manufacturing-capacity-sharing-model-merck-co-andmedimmune-llc-0

Van Lange, P. A., \& Semin-Goossens, A. (1998). The boundaries of reciprocal cooperation. European Journal of Social Psychology, 28, 847-857.

Vargo, S. L., \& Lusch, R. F. (2004). Evolving to a new dominant logic for marketing. Journal of Marketing, 68(1), 1-17.

Visnjic, I., Neely, A., Cennamo, C., \& Visnjic, N. (2016). Governing the city: Unleashing value from the business ecosystem. California Management Review, 59(1), 109-140. 
Wind, Y. J., Fung, V., \& Fung, W. (2009). Network orchestration: creating and managing global supply chains without owning them. In The network challenge: strategy, profit, and risk in an interlinked world. Kleindorfer, P.R., Wind, Y., Wind, Y.J., Gunther, R.E. (Eds.). New Jersey: Wharton School Publishing.

Winn, M. I. (2001). Building stakeholder theory with a decision modeling methodology. Business \& Society, 40(2), 133-166.

Wosskow, D. (2014). Unlocking the sharing economy: An independent review. London: Department for Business, Innovation and Skills. Retrieved 16 March 2018 from http://collaborativeeconomy.com/wp/wp-content/uploads/2015/04/WosskowD.2014.Unlocking-the-UK-Sharing-Economy.pdf

Yu, H. (2017). Marriott and Hilton stay ahead of the sharing economy, proving that Airbnb is not the Uber of hotels. Forbes. Retrieved 16 March 2018 from https://www.forbes.com/sites/howardhyu/2017/02/16/marriott-and-hilton-stay-ahead-ofthe-sharing-economy-proving-that-airbnb-is-not-the-uber-of-hotels/\#381c5f3776b3

Zervas, G., Proserpio, D., \& Byers, J. W. (2017). The rise of the sharing economy: Estimating the impact of Airbnb on the hotel industry. Journal of Marketing Research, 54(5), 687-705.

Zhu, F., \& Furr, N. (2016). Products to platforms: Making the leap. Harvard Business Review, 94(4), 72-78. 
Table 1.

\begin{tabular}{|c|c|c|}
\hline Value driver & Traditional venue industry & Headbox disruption \\
\hline Transparency & $\begin{array}{l}\text { None to very low transparency - } \\
\text { the role of venue providers is to } \\
\text { build barriers among } \\
\text { stakeholders to maintain control, } \\
\text { usually withholding contact } \\
\text { information, data, price, and thus } \\
\text { disabling direct communication } \\
\text { and value co-creation among } \\
\text { stakeholders. }\end{array}$ & $\begin{array}{l}\text { Full transparency - enabling } \\
\text { stakeholders to directly } \\
\text { communicate with one another, } \\
\text { sharing data and knowledge } \\
\text { about other stakeholders and } \\
\text { maintaining flexible, but fully } \\
\text { transparent, pricing. }\end{array}$ \\
\hline $\begin{array}{l}\text { Price elasticity } \\
\& \text { flexible } \\
\text { pricing options }\end{array}$ & $\begin{array}{l}\text { Inability to facilitate and support } \\
\text { different pricing preference and } \\
\text { requirements of diverse venue } \\
\text { providers - imposing a } \\
\text { standardised pricing model on all } \\
\text { stakeholders. }\end{array}$ & $\begin{array}{l}\text { To improve efficiency within the } \\
\text { wider industry, Headbox initially } \\
\text { introduced flexible pricing (over } \\
250 \text { possible pricing } \\
\text { combinations) and recently } \\
\text { launched fully dynamic pricing. }\end{array}$ \\
\hline $\begin{array}{l}\text { Variety I venue } \\
\text { choices }\end{array}$ & $\begin{array}{l}\text { Lack of new venue openings - } \\
\text { focused on traditional, easily } \\
\text { accessible venues such as hotel } \\
\text { meeting rooms and conference } \\
\text { centres. Imposing standard } \\
\text { venues on } \\
\text { customers/stakeholders who } \\
\text { have a multitude of different } \\
\text { needs. }\end{array}$ & $\begin{array}{l}\text { Widening venue choices to } \\
\text { creative and non-traditional } \\
\text { places by identifying 'idle' } \\
\text { assets/unused spaces and thus } \\
\text { accommodating diverse needs of } \\
\text { venue seekers (venues range } \\
\text { from opera houses through to } \\
\text { warehouses, ateliers and remote } \\
\text { tree houses). }\end{array}$ \\
\hline $\begin{array}{l}\text { Technology } \\
\text { adoption }\end{array}$ & $\begin{array}{l}\text { Very low adoption and integration } \\
\text { of new technologies - industry } \\
\text { adheres to standard 'directory } \\
\text { listing' approach. Within industry } \\
\text { there is no support for real-time } \\
\text { information (RTI) and collection } \\
\text { and use of 'rich' data. }\end{array}$ & $\begin{array}{l}\text { Addressing industry inefficiencies } \\
\text { through technology - } \\
\text { development of digital } \\
\text { marketplace with 'rich' data being } \\
\text { central to the success of both } \\
\text { Headbox and its diverse } \\
\text { stakeholders. }\end{array}$ \\
\hline $\begin{array}{l}\text { Role of } \\
\text { intermediary }\end{array}$ & $\begin{array}{l}\text { To facilitate transaction between } \\
\text { stakeholders without enabling } \\
\text { their direct contact - maintaining } \\
\text { distance between different } \\
\text { customers (stakeholders). }\end{array}$ & $\begin{array}{l}\text { Acting as a 'central actor' - } \\
\text { facilitating and aiding two-way } \\
\text { communication between different } \\
\text { customers. Headbox is } \\
\text { minimising distance between } \\
\text { stakeholders. }\end{array}$ \\
\hline $\begin{array}{l}\text { Breadth of } \\
\text { stakeholder }\end{array}$ & $\begin{array}{l}\text { Usually focused on addressing } \\
\text { one or very limited needs of }\end{array}$ & $\begin{array}{l}\text { Focused on addressing wide } \\
\text { range of needs for a }\end{array}$ \\
\hline
\end{tabular}




\begin{tabular}{|c|c|c|}
\hline $\begin{array}{l}\text { needs } \\
\text { addressed }\end{array}$ & $\begin{array}{l}\text { many diverse stakeholders - 'few } \\
\text { of many'. }\end{array}$ & $\begin{array}{l}\text { specific/limited number of } \\
\text { stakeholders - 'many of few'. }\end{array}$ \\
\hline $\begin{array}{l}\text { Level of } \\
\text { standardisation }\end{array}$ & $\begin{array}{l}\text { Imposing general standards that } \\
\text { all stakeholders need to adhere } \\
\text { to (i.e., pricing, cancellation } \\
\text { policy) - standardising everything } \\
\text { to maintain control over all } \\
\text { stakeholders. }\end{array}$ & $\begin{array}{l}\text { Supporting and encouraging } \\
\text { stakeholder diversity by } \\
\text { accommodating their existing } \\
\text { processes and limitations - not } \\
\text { standardising what does not } \\
\text { need to be standardised and } \\
\text { thus empowering stakeholders. }\end{array}$ \\
\hline $\begin{array}{l}\text { Data \& } \\
\text { stakeholder } \\
\text { feedback }\end{array}$ & $\begin{array}{l}\text { Data capture is often transaction } \\
\text { focused with limited focus on rich } \\
\text { data. Lacking mechanisms to } \\
\text { collect granular and actionable } \\
\text { feedback from stakeholders. } \\
\text { Data is used only by } \\
\text { intermediary, often for monitoring } \\
\text { purposes. }\end{array}$ & $\begin{array}{l}\text { Capturing and unifying rich data } \\
\text { with focus on stakeholder } \\
\text { engagement and experience. } \\
\text { Using technology to collect } \\
\text { granular and actionable feedback } \\
\text { (specific to particular aspect of } \\
\text { offering). Data is shared across } \\
\text { platform to continuously improve } \\
\text { different aspects of wider offering } \\
\text { (each stakeholder can do } \\
\text { something better based on data). }\end{array}$ \\
\hline $\begin{array}{l}\text { Stakeholder } \\
\text { barriers to } \\
\text { purchase }\end{array}$ & $\begin{array}{l}\text { Using rigid processes that often } \\
\text { discourage stakeholders to } \\
\text { purchase (i.e., imposed invoicing } \\
\text { mechanism). }\end{array}$ & $\begin{array}{l}\text { Strong focus on removing actual } \\
\text { and perceived barriers to take up } \\
\text { offering. }\end{array}$ \\
\hline $\begin{array}{l}\text { Stakeholder } \\
\text { integration }\end{array}$ & $\begin{array}{l}\text { Isolating rather than integrating } \\
\text { stakeholders, leading to very } \\
\text { limited value co-creation } \\
\text { opportunities within the platform. } \\
\text { Intermediaries are aiming to } \\
\text { 'exploit' each side of the market - } \\
\text { 'divide and conquer'. }\end{array}$ & $\begin{array}{l}\text { Integrating stakeholders to } \\
\text { facilitate and promote value co- } \\
\text { creation within the platform. }\end{array}$ \\
\hline $\begin{array}{l}\text { Customer } \\
\text { retention }\end{array}$ & $\begin{array}{l}\text { Business strategy focused on } \\
\text { customer acquisition rather than } \\
\text { retention. Intermediaries struggle } \\
\text { to retain customers by their lack } \\
\text { of focus on their wider needs. }\end{array}$ & $\begin{array}{l}\text { Accommodating wider needs of } \\
\text { customers and continuously } \\
\text { innovating the offering to appeal } \\
\text { to all stakeholders involved. } \\
\text { Business strategy is focused on } \\
\text { retention by creating superior } \\
\text { stakeholder experience. }\end{array}$ \\
\hline $\begin{array}{l}\text { Stakeholder } \\
\text { management \& } \\
\text { control }\end{array}$ & $\begin{array}{l}\text { Transaction-based. Purposefully } \\
\text { reducing visibility and } \\
\text { stakeholder control to get them } \\
\text { 'locked in'. }\end{array}$ & $\begin{array}{l}\text { Relationship-driven. Increasing } \\
\text { visibility, engagement and } \\
\text { empowering stakeholders to } \\
\text { increase 'stickiness' of the } \\
\text { offering. }\end{array}$ \\
\hline
\end{tabular}


Table 2.

\begin{tabular}{|c|c|c|c|c|c|c|c|c|c|}
\hline Phase & \multicolumn{3}{|c|}{ Phase 1: Developing basic offering } & \multicolumn{3}{|c|}{ Phase 2: Extending offering and platform } & \multicolumn{3}{|c|}{ Phase 3: Platform management and leverage } \\
\hline Short narrative & \multicolumn{3}{|c|}{$\begin{array}{l}\text { Headbox focused on attracting two different groups of } \\
\text { stakeholders - venue owners (hosts) and venue } \\
\text { seekers (guests) - to its platform. However, Headbox } \\
\text { was only generating revenue from the host side of the } \\
\text { market, where it was charging commission on } \\
\text { bookings. Along the basic revenue model, the company } \\
\text { has identified a non-monetary but strategically } \\
\text { important way to capture value through collection and } \\
\text { unification of different customer-rich data (combination } \\
\text { of transactional, behavioral, engagement and } \\
\text { experience data). In doing so, over time Headbox was } \\
\text { able to build a more accurate picture of their } \\
\text { stakeholders. By collecting rich data from multiple } \\
\text { touchpoints, Headbox soon realized that a large } \\
\text { number of their business customers come from } \\
\text { different functions of the same. This was an initial } \\
\text { impulse to launch the Corporate Dashboard (Phase 2). } \\
\text { Its role was to reduce this fragmentation (i.e., several } \\
\text { individual accounts from the same company) and to } \\
\text { create value for these corporations by improving their } \\
\text { budget control and internal transparency. The } \\
\text { Corporate Dashboard aggregates these individual } \\
\text { accounts under one 'roof' and offers corporations } \\
\text { valuable insights through the provision of data. So far, } \\
\text { Headbox's Corporate Dashboard is used by more than } \\
100 \text { blue chip corporates, including HSBC, Uber, and } \\
\text { Expedia. By launching the Corporate Dashboard, } \\
\text { Headbox entered its second phase of development. }\end{array}$} & \multicolumn{3}{|c|}{$\begin{array}{l}\text { Headbox started increasing not the only value that it } \\
\text { created for its stakeholders but also the number of } \\
\text { stakeholders that it integrated into the platform (i.e., } \\
\text { third-party services, corporates). This led to an increase } \\
\text { in revenue streams that Headbox was able to generate } \\
\text { from different stakeholder groups. Besides the } \\
\text { commission fee from venues, Headbox was also } \\
\text { generating revenue from annual subscription fees for } \\
\text { Corporate Dashboards, paid-for services for hosts (i.e., } \\
\text { professional photography, 3D tours and premium } \\
\text { listing) and listing fees for third-party suppliers. During } \\
\text { the second phase, Headbox, rather than solely focusing } \\
\text { on growing its stakeholder base, focused instead on } \\
\text { increasing the commitment and involvement of existing } \\
\text { stakeholders, which led to a significantly higher } \\
\text { retention rate. For example, many of the corporate } \\
\text { clients started using Headbox exclusively for all their } \\
\text { event needs. The rising commitment to the platform } \\
\text { also became evident among the hosts, who started } \\
\text { investing more into improving their listings by adding } \\
\text { professional photography and 3D tours, and by } \\
\text { improving their performance (acting upon feedback } \\
\text { provided by guests and Headbox). In other words, } \\
\text { Headbox started to become the only platform these } \\
\text { hosts used for getting bookings. Lastly, this } \\
\text { commitment to continuous improvement and innovation } \\
\text { had positively impacted on the uptake and regularity } \\
\text { with which businesses used the platform. }\end{array}$} & \multicolumn{3}{|c|}{$\begin{array}{l}\text { During the last phase, Headbox kept focusing on further } \\
\text { widening the value it creates for its diverse stakeholders } \\
\text { while exploring new revenue opportunities. Size and } \\
\text { complexity of the network grew significantly and } \\
\text { Headbox decided to focus on maintaining its full control } \\
\text { without restricting its stakeholders (i.e., through } \\
\text { unnecessary standardization). From a technical } \\
\text { perspective, Headbox aimed to maintain its speed and } \\
\text { flexibility of innovation, but also to increase technological } \\
\text { manageability of the platform, and initiated a move from } \\
\text { monolithic to modular product architecture. In other } \\
\text { words, Headbox started to 'break down the single } \\
\text { monolithic product into isolated components. As the } \\
\text { platform evolves it tends to get bigger, until it hit the } \\
\text { point when any changes or incremental improvements } \\
\text { are slowing down because the risks grow with the size of } \\
\text { the product, which requires a lot of investment and effort } \\
\text { into testing and managing that impact' (head of product). } \\
\text { In addition to moving away from monolithic architecture, } \\
\text { during this phase Headbox also managed to extend its } \\
\text { offering beyond its immediate platform by introducing a } \\
\text { payment engine that can be used as a standalone } \\
\text { product. In doing so, Headbox helped its existing hosts } \\
\text { to integrate all their bookings from across different } \\
\text { channels. By having this level of real-time visibility into } \\
\text { all venues' bookings, Headbox started developing } \\
\text { dynamic pricing that benefited both hosts and guests. }\end{array}$} \\
\hline $\begin{array}{l}\text { Main } \\
\text { stakeholder } \\
\text { group/ core } \\
\text { activities }\end{array}$ & $\begin{array}{l}\text { Drawing } \\
\text { stakeholders } \\
\text { in }\end{array}$ & $\begin{array}{l}\text { Keeping } \\
\text { stakeholders } \\
\text { in }\end{array}$ & $\begin{array}{l}\text { Monetising } \\
\text { opportunities } \\
\text { (value capture) }\end{array}$ & $\begin{array}{l}\text { Drawing } \\
\text { stakeholders } \\
\text { in }\end{array}$ & $\begin{array}{l}\text { Keeping } \\
\text { stakeholders } \\
\text { in }\end{array}$ & $\begin{array}{l}\text { Monetising } \\
\text { opportunities } \\
\text { (value } \\
\text { capture) }\end{array}$ & $\begin{array}{l}\text { Drawing } \\
\text { stakeholders } \\
\text { in }\end{array}$ & $\begin{array}{l}\text { Keeping } \\
\text { stakeholders } \\
\text { in }\end{array}$ & $\begin{array}{l}\text { Monetising } \\
\text { opportunities } \\
\text { (value capture) }\end{array}$ \\
\hline
\end{tabular}




\begin{tabular}{|c|c|c|c|c|c|c|c|c|c|}
\hline $\begin{array}{l}\text { B2B guests } \\
\text { (single } \\
\text { business } \\
\text { users) }\end{array}$ & $\begin{array}{l}\text { - Ability to } \\
\text { easily search, } \\
\text { book and pay } \\
\text { for unique and } \\
\text { creative } \\
\text { venues that } \\
\text { meet wider } \\
\text { needs; all in } \\
\text { one } \\
\text { place/platform }\end{array}$ & $\begin{array}{l}\text {-Maintaining } \\
\text { free access } \\
\text { to an easy-to- } \\
\text { use platform } \\
\text {-Increasing } \\
\text { variety and } \\
\text { type of } \\
\text { venues } \\
\text { offered }\end{array}$ & $\begin{array}{l}\text { - Ability to } \\
\text { collect } \\
\text { transactional } \\
\text { data (not } \\
\text { directly) }\end{array}$ & $\begin{array}{l}\text { - Ability to } \\
\text { easily search, } \\
\text { book and pay } \\
\text { for unique and } \\
\text { creative venues } \\
\text { that meet wider } \\
\text { needs; all in } \\
\text { one } \\
\text { place/platform } \\
\text { - } \\
\text { Accommodatin } \\
\text { g stakeholders' } \\
\text { existing } \\
\text { processes and } \\
\text { preferences } \\
\text { (removing } \\
\text { barriers to use } \\
\text { platform) }\end{array}$ & $\begin{array}{l}\text { - Maintaining } \\
\text { free access } \\
\text { to an easy-to- } \\
\text { use platform } \\
\text { - Increasing } \\
\text { variety and } \\
\text { type of } \\
\text { venues } \\
\text { offered } \\
\text { - Enabling } \\
\text { free access } \\
\text { to basic third- } \\
\text { party services } \\
\text {-Encouraging } \\
\text { feedback and } \\
\text { stakeholder } \\
\text { engagement }\end{array}$ & $\begin{array}{l}\text { - Ability to } \\
\text { collect richer } \\
\text { data based on } \\
\text { transactions, } \\
\text { behavior, and } \\
\text { engagement } \\
\text { (not monetized } \\
\text { directly) }\end{array}$ & $\begin{array}{l}\text { - Ability to } \\
\text { easily search, } \\
\text { book and pay } \\
\text { for unique and } \\
\text { creative } \\
\text { venues that } \\
\text { meet wider } \\
\text { needs; all in } \\
\text { one } \\
\text { place/platform } \\
\text { - } \\
\text { Accommodati } \\
\text { ng } \\
\text { stakeholders' } \\
\text { existing } \\
\text { processes and } \\
\text { preferences } \\
\text { (removing } \\
\text { barriers to use } \\
\text { platform) } \\
\text { - Ability to } \\
\text { access RT } \\
\text { (real-time) } \\
\text { pricing and } \\
\text { availability } \\
\text { data }\end{array}$ & $\begin{array}{l}\text {-Maintaining } \\
\text { free access to } \\
\text { an easy-to-use } \\
\text { platform } \\
\text { - Increasing } \\
\text { variety and } \\
\text { type of venues } \\
\text { - Enabling free } \\
\text { access to a } \\
\text { wide range of } \\
\text { third-party } \\
\text { services } \\
\text {-Encouraging } \\
\text { feedback and } \\
\text { stakeholder } \\
\text { engagement } \\
\text {-Continuous } \\
\text { improvement } \\
\text { of the offering }\end{array}$ & $\begin{array}{l}\text { - Ability to } \\
\text { collect and unify } \\
\text { rich data based } \\
\text { on transaction, } \\
\text { behavior, } \\
\text { engagement, } \\
\text { and experience } \\
\text { (not monetized } \\
\text { directly) }\end{array}$ \\
\hline $\begin{array}{l}\text { Hosts } \\
\text { (venue } \\
\text { providers) }\end{array}$ & $\begin{array}{l}\text { - Additional } \\
\text { exposure to a } \\
\text { vast range of } \\
\text { relevant } \\
\text { customers }\end{array}$ & $\begin{array}{l}\text { - Free listing } \\
\text { on the } \\
\text { platform } \\
\text {-Access to } \\
\text { high-end } \\
\text { tools to better } \\
\text { present and } \\
\text { sell venues }\end{array}$ & $\begin{array}{l}\text {-Commission } \\
\text { (\%) from the } \\
\text { price paid by } \\
\text { 'guests' }\end{array}$ & $\begin{array}{l}\text { - Additional } \\
\text { exposure to the } \\
\text { vast range of } \\
\text { relevant } \\
\text { customers } \\
\text { - } \\
\text { Accommodatin } \\
\text { g stakeholders' } \\
\text { existing } \\
\text { preferences } \\
\text { and processes } \\
\text { (i.e., custom } \\
\text { cancellation } \\
\text { policy or } \\
\text { flexible pricing) }\end{array}$ & $\begin{array}{l}\text { - Free listing } \\
\text { on the } \\
\text { platform and } \\
\text { use of } \\
\text { premium } \\
\text { placement } \\
\text { - Continuous } \\
\text { improvement } \\
\text { of available } \\
\text { tools to help } \\
\text { stakeholders } \\
\text { to improve } \\
\text { sales (i.e., } \\
\text { 3D, virtual } \\
\text { tours) } \\
\text { - Ability to } \\
\text { use flexible } \\
\text { pricing }\end{array}$ & $\begin{array}{l}\text { - Commission } \\
\text { (\%) from the } \\
\text { price paid by } \\
\text { 'guests' } \\
\text { - Additional } \\
\text { revenue from } \\
\text { paid placement } \\
\text { on generic } \\
\text { venue } \\
\text { collection } \\
\text { pages } \\
\text { - Fixed fee for } \\
\text { the provision of } \\
\text { additional } \\
\text { services } \\
\text { (photography, } \\
\text { 3D) }\end{array}$ & $\begin{array}{l}\text { - Additional } \\
\text { exposure to } \\
\text { the vast range } \\
\text { of relevant } \\
\text { customers } \\
\text { - } \\
\text { Accommodati } \\
\text { ng } \\
\text { stakeholders' } \\
\text { existing } \\
\text { preferences } \\
\text { and processes } \\
\text { (i.e., custom } \\
\text { cancellation } \\
\text { policy or } \\
\text { flexible } \\
\text { pricing) }\end{array}$ & $\begin{array}{l}\text { - Free listing } \\
\text { on the platform } \\
\text { and use of } \\
\text { premium } \\
\text { placement } \\
\text {-Continuous } \\
\text { improvement } \\
\text { of available } \\
\text { tools to help } \\
\text { stakeholders } \\
\text { to improve } \\
\text { sales (i.e., 3D, } \\
\text { virtual tours) } \\
\text { - Ability to use } \\
\text { dynamic RT } \\
\text { (real-time) } \\
\text { pricing } \\
\text { - Ability to } \\
\text { access and } \\
\text { use unified RT } \\
\text { (real-time) } \\
\text { customer data }\end{array}$ & $\begin{array}{l}\text { - Commission } \\
\text { (\%) from the } \\
\text { price paid by } \\
\text { 'guests' } \\
\text { - Additional } \\
\text { revenue from } \\
\text { paid placement } \\
\text { on generic } \\
\text { venue collection } \\
\text { pages } \\
\text { - Fixed fee for } \\
\text { the provision of } \\
\text { additional } \\
\text { services } \\
\text { (photography, } \\
\text { 3D) } \\
\text { - Fixed } \\
\text { subscription fee } \\
\text { to 'widget' } \\
\text { (booking } \\
\text { management } \\
\text { add-on for } \\
\text { venues } \\
\text { (monetizing } \\
\text { data directly) }\end{array}$ \\
\hline
\end{tabular}




\begin{tabular}{|c|c|c|c|c|c|c|c|c|c|}
\hline $\begin{array}{l}\text { Corporate } \\
\text { guests } \\
\text { (aggregated } \\
\text { business } \\
\text { users) }\end{array}$ & - & - & - & $\begin{array}{l}\text {-Transparency, } \\
\text { budget control, } \\
\text { and } \\
\text { convenience } \\
\text { through } \\
\text { consolidation of } \\
\text { business } \\
\text { functions (using } \\
\text { one account for } \\
\text { all business } \\
\text { functions - } \\
\text { reducing } \\
\text { fragmentation) }\end{array}$ & $\begin{array}{l}\text { - Access to } \\
\text { the unified } \\
\text { corporate } \\
\text { platform } \\
\text { (dashboard) } \\
\text { - Increasing } \\
\text { variety and } \\
\text { type of } \\
\text { venues } \\
\text { offered } \\
\text { - Provision of } \\
\text { RT (real-time) } \\
\text { data }\end{array}$ & $\begin{array}{l}\text { - Annual } \\
\text { subscription } \\
\text { fee to the } \\
\text { corporate } \\
\text { platform } \\
\text { - Commission } \\
(\%) \text { from } \\
\text { bookings and } \\
\text { additional } \\
\text { services }\end{array}$ & $\begin{array}{l}\text { - } \\
\text { Transparency, } \\
\text { budget } \\
\text { control, and } \\
\text { convenience } \\
\text { through } \\
\text { consolidation } \\
\text { of business } \\
\text { functions } \\
\text { (using one } \\
\text { account for all } \\
\text { business } \\
\text { functions - } \\
\text { reducing } \\
\text { fragmentation) }\end{array}$ & $\begin{array}{l}\text { - Access to the } \\
\text { unified } \\
\text { corporate } \\
\text { platform } \\
\text { (dashboard) } \\
\text { - Increasing } \\
\text { variety and } \\
\text { type of venues } \\
\text { offered } \\
\text { - Provision of } \\
\text { RT (real-time) } \\
\text { data } \\
\text { - } \\
\text { Personalisatio } \\
\mathrm{n} \text { and account } \\
\text { management } \\
\text {-Continuous } \\
\text { improvement } \\
\text { of the platform } \\
\text { and } \\
\text { functionality }\end{array}$ & $\begin{array}{l}\text { - Annual } \\
\text { subscription fee } \\
\text { to the corporate } \\
\text { platform } \\
\text { - Commission } \\
\text { (\%) from } \\
\text { bookings and } \\
\text { additional third- } \\
\text { party services }\end{array}$ \\
\hline $\begin{array}{l}\text { Third party } \\
\text { service } \\
\text { providers } \\
\text { (friends) }\end{array}$ & - & - & - & $\begin{array}{l}\text { - Additional } \\
\text { exposure to the } \\
\text { vast range of } \\
\text { relevant } \\
\text { customers and } \\
\text { varied } \\
\text { marketing tools }\end{array}$ & $\begin{array}{l}\text { - Listing on } \\
\text { platform } \\
\text { - Ensured } \\
\text { continuous } \\
\text { business } \\
\text { (Headbox is } \\
\text { keeping the } \\
\text { number of } \\
\text { listed third- } \\
\text { party service } \\
\text { providers } \\
\text { low) }\end{array}$ & $\begin{array}{l}\text { - Annual listing } \\
\text { fee }\end{array}$ & $\begin{array}{l}\text { - } \\
\text { Increased/add } \\
\text { itional } \\
\text { exposure to } \\
\text { relevant } \\
\text { customers } \\
\text { and varied } \\
\text { marketing } \\
\text { tools }\end{array}$ & $\begin{array}{l}\text { - Listing on } \\
\text { platform } \\
\text { - Ensured } \\
\text { continuous } \\
\text { business } \\
\text { (Headbox is } \\
\text { keeping the } \\
\text { number of } \\
\text { competing } \\
\text { service } \\
\text { providers low) } \\
\text { - Ability to use } \\
\text { flexible/dynami } \\
\text { c pricing (not } \\
\text { yet } \\
\text { implemented) }\end{array}$ & $\begin{array}{l}\text { - Annual listing } \\
\text { fee } \\
\text { - Commission } \\
\text { from services } \\
\text { sold }\end{array}$ \\
\hline $\begin{array}{l}\text { Independent } \\
\text { hosts (using } \\
\text { widget but not } \\
\text { necessarily } \\
\text { platform) }\end{array}$ & - & - & - & - & - & - & $\begin{array}{l}\text {-Independent } \\
\text { all-in-one } \\
\text { venue } \\
\text { booking/pricin } \\
\text { g } \\
\text { management } \\
\text { tool for } \\
\text { existing and } \\
\text { independent } \\
\text { hosts (not } \\
\text { using } \\
\text { Headbox } \\
\text { platform) }\end{array}$ & $\begin{array}{l}\text { - Ability to } \\
\text { effectively } \\
\text { manage the } \\
\text { bookings and } \\
\text { use dynamic } \\
\text { pricing } \\
\text { - Access to } \\
\text { unified data } \\
\text { from across all } \\
\text { channels } \\
\text { - High level of } \\
\text { integration to } \\
\text { other services } \\
\text { (API based) }\end{array}$ & $\begin{array}{l}\text { - Subscription to } \\
\text { service } \\
\text { (monetized } \\
\text { directly) } \\
\text { - Ability to } \\
\text { collect and unify } \\
\text { rich data (not } \\
\text { monetized } \\
\text { directly) }\end{array}$ \\
\hline
\end{tabular}


